\title{
Stratigraphy and Depositional Environments of Sediments from Five Cores from Screven and Burke Counties, Georgia
}

By W. Fred Falls and David C. Prowell

\section{U.S. GEOLOGICAL SURVEY PROFESSIONAL PAPER 1603-A}




\section{CONTENTS}

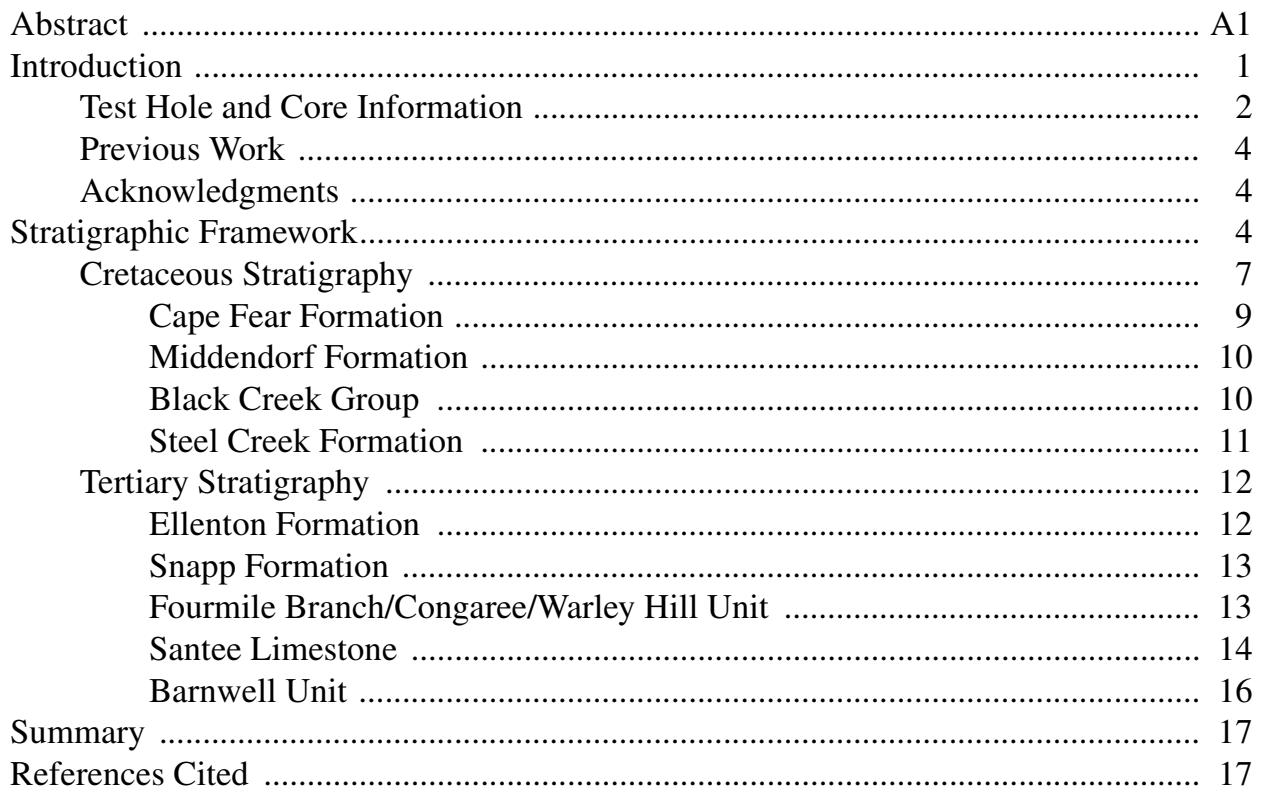

\section{FIGURES}

1. Index map showing the Savannah River Site and the location of stratigraphic test holes in the study area

2. Correlation diagram showing a generalized comparison of Cretaceous and Tertiary geologic units in the Southeastern United States

3-5. Gamma-ray, single-point resistance, and lithologic logs and geologic units of the-

3. Millhaven test hole in Screven County, Ga

4. Girard test hole in Burke County, Ga.

5. Millers Pond test well 1 and test hole in Burke County, Ga

6. Gamma-ray, single-point resistance, and lithologic logs (from figs. 3-5) showing dip-oriented correlation

of geologic units from the Millers Pond test hole to the Millhaven test hole

\section{TABLE}

1. Elevations and depths of stratigraphic tops for geologic units and subunits in the Millhaven, Girard,

Thompson Oak, Millers Pond, and McBean cores 


\title{
Stratigraphy and Depositional Environments of Sediments from Five Cores from Screven and Burke Counties, Georgia
}

\author{
By W. Fred Falls and David C. Prowell
}

\begin{abstract}
Five deep stratigraphic test holes were drilled from 1991 to 1993 in support of multidisciplinary investigations to determine the stratigraphy of Upper Cretaceous and Tertiary sediments of the coastal plain in east-central Georgia. Cored sediment and geophysical logs from the Millhaven test hole in Screven County and the Girard and Millers Pond test holes in Burke County are the primary sources of lithologic and paleontologic information for this report. Lithologic and paleontologic information from the Thompson Oak and McBean test holes in Burke County supplements the discussion of stratigraphy and sedimentation in the updip part of the study area near the Millers Pond test hole.

The Cretaceous sections in the studied cores are divided into the Cape Fear Formation, the Middendorf Formation, the Black Creek Group, and the Steel Creek Formation. These four geologic units consist of siliciclastic sediments. Evidence of possible unconformities allows us to recognize two subunits in the Middendorf Formation and three subunits in the Black Creek Group. Sediments in the Cretaceous section generally are coarser grained and more oxidized in updip areas. Each contact between units is a regional unconformity and denotes a considerable hiatus in sedimentation. The sediments in all four geologic units have been interpreted as being part of large deltaic systems that prograded across the paleo-continental shelf in east-central Georgia and western South Carolina. The lithofacies observed in the Upper Cretaceous units tend to be coarser grained in proximal-deltaic environments and finer grained in distal-deltaic environments.

The Tertiary sections are divided into the Ellenton and Snapp Formations of Paleocene age; the Fourmile Branch/ Congaree/Warley Hill unit and Santee Limestone of Eocene age; and the Barnwell unit, which contains strata of Eocene to Miocene age. The Tertiary section, with the exception of
\end{abstract}

the Snapp Formation, generally is more calcareous and has a more diverse and abundant marine microflora and fauna in the downdip Millhaven core, relative to the updip McBean and Millers Pond cores. For these units, sedimentary and paleontologic evidence suggests open-marine shelf environments at the Millhaven site and marginal-marine environments at the Millers Pond site.

The Snapp Formation is nearly barren of fossils and is a noncalcareous sequence of oxidized sand and clay. Sedimentary characteristics of the Snapp Formation suggest a fluvially dominated depositional environment such as an upper delta plain or an incised alluvial valley. The presence of a sparse marine microflora suggests some marine influence on deposition in the downdip area near Millhaven. Differences in the thickness of this formation in the study area suggest that channels containing the basal sand of the Snapp Formation are incised into laminated black clay of the Ellenton Formation.

\section{INTRODUCTION}

Five deep stratigraphic test holes were drilled in east-central Georgia from 1991 to 1993 in support of multidisciplinary investigations by the U.S. Geological Survey (USGS) and the Georgia Geologic Survey (GGS) of the Georgia Department of Natural Resources. These investigations were conducted to determine the geology and hydrology of the Georgia Coastal Plain sediments in the vicinity of the U.S. Department of Energy Savannah River Site (SRS) in South Carolina (fig. 1). In this region, poorly consolidated Cretaceous and Cenozoic strata form a southeastward-thickening wedge of fluvial and marine deposits underlain by Paleozoic crystalline rocks and Triassic-Jurassic sedimentary rocks. This wedge of sediment is more than 


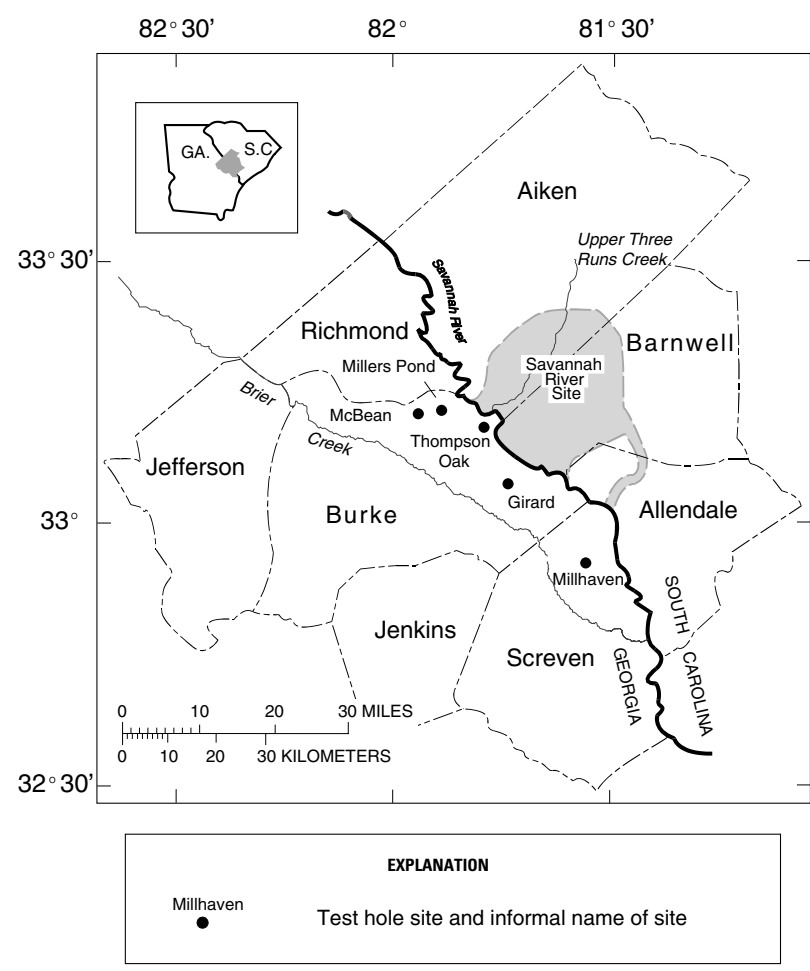

Figure 1. Index map showing the Savannah River Site and the location of stratigraphic test holes in the study area.

$1,450 \mathrm{ft}$ thick in the downdip Millhaven core in Screven County.

Previously, the Upper Cretaceous section in the subsurface of the study area was penetrated partially by four cored test holes along the Savannah River in Burke County (Bechtel Corporation, 1972) and by a cored test hole near the town of Midville in the southwestern corner of Burke County (Prowell, Christopher, and others, 1985). The Cretaceous section also was studied by using geophysical logs and cuttings from local water wells (Clarke and others, 1985). The sedimentary history and stratigraphy of the Tertiary section in the study area already were known from outcrops (Huddlestun and Hetrick, 1978, 1979, 1986; Hetrick, 1992) and from several fully or partially cored test holes in northern Burke County (McClelland, 1987) and along the Savannah River in Burke and Screven Counties (Bechtel Corporation, 1972).

This chapter briefly describes the lithologic and stratigraphic character of the geologic units (fig. 2) recognized in the five cored sections to provide a framework for detailed discussions of the fauna and flora identified from paleontologic efforts. The paleontologic data presented in the other chapters of this volume are used with the core descriptions to infer correlation of these geologic units with stratigraphically equivalent units in the vicinity of the study area and to infer depositional environments.

\section{TEST HOLE AND CORE INFORMATION}

The five test holes informally are named for local landmarks and formally are assigned either a GGS or a USGS identification number. The informal names used in this report are Millhaven, Girard, Thompson Oak, Millers Pond, and McBean. The five test holes were continuously cored with a wireline, mud-rotary coring system. The cores from the Millhaven, Girard, and Millers Pond test holes were examined for texture, mineralogy, sedimentary structures, diagenetic features, and the presence of macrofossils. Selected samples were examined microscopically for dinoflagellates, pollen, foraminifers, ostracodes, and calcareous nannofossils. The descriptions of the cores and the geophysical logs of the associated test holes at Millhaven, Girard, and Millers Pond are the primary sources of information for the following discussion of stratigraphic units (Clarke and others, 1994, 1996; Leeth and others, 1996).

The authors interpreted the stratigraphy of the Thompson Oak and McBean cores from descriptions published by the GGS (Huddlestun and Summerour, 1996) and have not personally examined these cores in detail. Samples for paleontologic examination were collected by P.F. Huddlestun of the GGS from the Thompson Oak and McBean cores. We used the paleontologic results (Frederiksen and others, this volume, chap. C; Edwards, this volume, chap. G; Frederiksen, this volume, chap. H) to interpret the stratigraphy and sedimentation of geologic units in the updip area near Millers Pond in Burke County, Ga. The stratigraphies of these two cores supplement the following discussion of stratigraphy in the updip part of Burke County near the Millers Pond test hole but are not illustrated as stratigraphic columns in this report.

Geophysical-logging surveys of the test holes, with the exception of the McBean test hole, include single-point and triple-point electric resistance, spontaneous potential, natural gamma ray, and hole diameter (caliper log). Formation instability and hole diameter of the Millhaven test hole prevented electric-logging surveys of the section from 571 to $530 \mathrm{ft}$ and triple-point resistance logging below $900 \mathrm{ft}$. The McBean test hole is the only one studied that was not geophysically logged.

Figure 2. Generalized comparison of Cretaceous and $>$ Tertiary geologic units in the Southeastern United States (modified from Clarke and others, 1994). Shaded areas indicate missing stratigraphic sections. Dashed lines indicate formation boundary of uncertain stratigraphic position. Abbreviation used: Fm, formation. Source for the lithologic units of eastern Georgia: Prowell, Christopher, and others (1985). Sources for the Georgia Geologic Survey nomenclature in eastern Georgia: Huddlestun and Hetrick (1991), Summerour and others (1994), and Huddlestun and Summerour (1996). Sources for units of South Carolina: Colquhoun and others (1983), Gohn (1992), and Fallaw and Price (1995). 


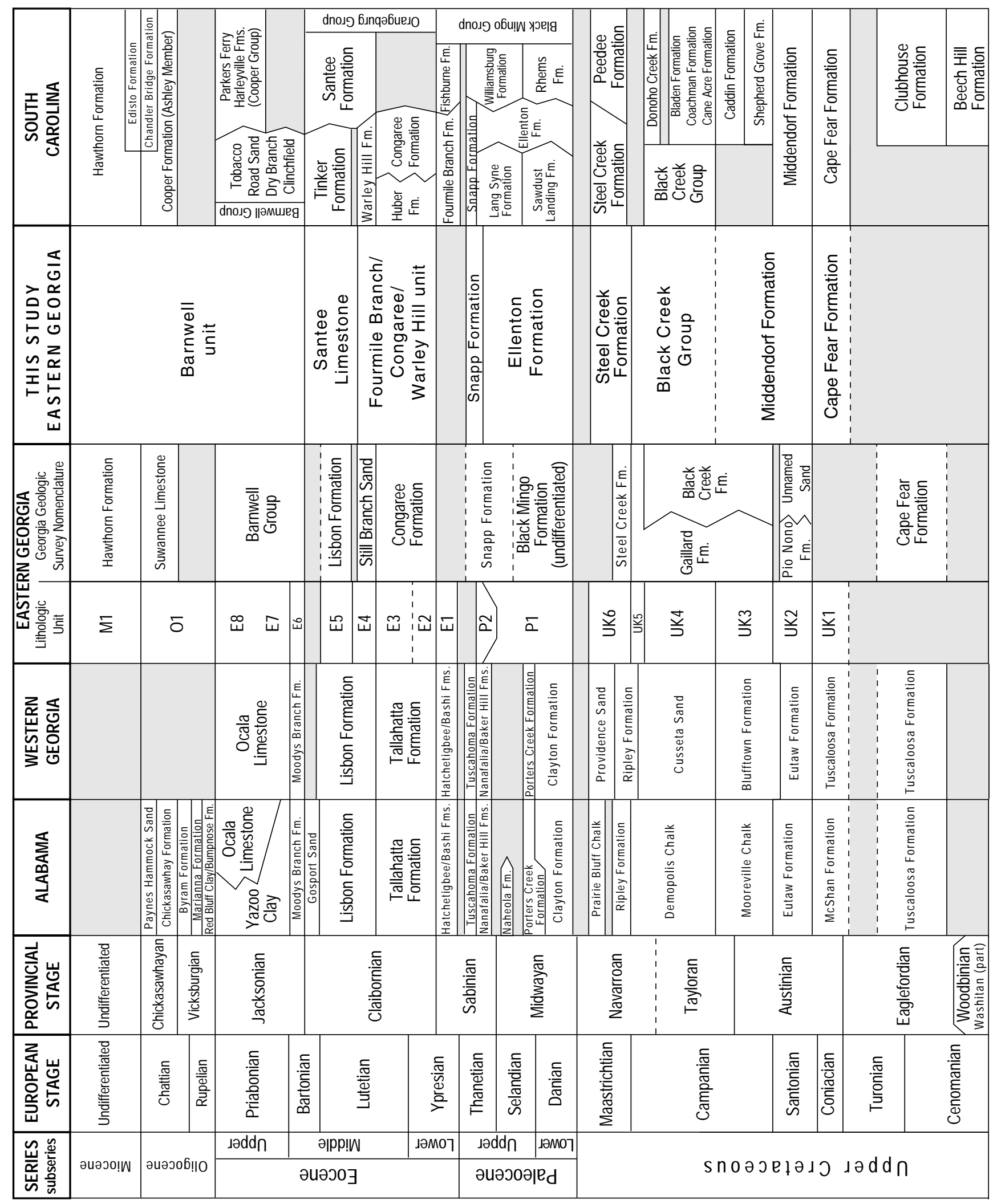


The Millhaven test hole was drilled by the USGS in late 1991 and early 1992 and formally designated as 33X048 (Clarke and others, 1996). The Millhaven site is located in Screven County, Ga., at lat 32 $533^{\prime 25}$ "N., long $81^{\circ} 35^{\prime} 43^{\prime \prime}$ W. (fig. 1) and has a land surface elevation of 110 $\mathrm{ft}$. The test hole was drilled from land surface to a total depth of 1,452 ft (fig. 3). This test hole was terminated in Upper Cretaceous sediments of the Cape Fear Formation and did not reach pre-Cretaceous rocks.

The USGS drilled the Girard test hole in the spring of 1992 and formally designated it as 32Y020 (Leeth and others, 1996). The Girard site is in Burke County, Ga., at lat $33^{\circ} 03^{\prime} 54^{\prime \prime}$ N., long $81^{\circ} 43^{\prime} 13^{\prime \prime}$ W. (fig. 1) and has a land surface elevation of $250 \mathrm{ft}$. The test hole was drilled from land surface to a total depth of $1,385 \mathrm{ft}$ and penetrated $1,375 \mathrm{ft}$ of coastal plain sediments (fig. 4) and $10 \mathrm{ft}$ of continental red beds of probable Triassic or Jurassic age (Siple, 1967; Marine, 1979; Prowell, Christopher, and others, 1985).

The GGS drilled the Thompson Oak test hole in early 1993 and formally designated it as GGS-3794 (Summerour and others, 1994; Huddlestun and Summerour, 1996); it is also known as TR92-6 and Burke 12. The drill site is located in Burke County, Ga., at lat $33^{\circ} 10^{\prime} 42^{\prime \prime}$ N., long $81^{\circ} 47^{\prime} 10^{\prime \prime}$ W. (fig. 1) and has a land surface elevation of 240 $\mathrm{ft}$. The test hole was drilled from land surface to a total depth of $1,010.5 \mathrm{ft}$ and penetrated $996 \mathrm{ft}$ of coastal plain sediments and $14.5 \mathrm{ft}$ of biotite gneiss of probable Paleozoic age.

The GGS drilled the Millers Pond test hole, also known as Burke 2, in the summer of 1991 and formally designated it as GGS-3758 (Clarke and others, 1994). The site is located in Burke County, Ga., at lat $33^{\circ} 13^{\prime} 48^{\prime \prime}$ N., long $81^{\circ} 52^{\prime} 44^{\prime \prime}$ W. (fig. 1) and has a land surface elevation of 245 $\mathrm{ft}$. The test hole was drilled from land surface to a total depth of $859 \mathrm{ft}$ and penetrated $852 \mathrm{ft}$ of coastal plain sediment (fig. 5) and $7 \mathrm{ft}$ of biotite-hornblende gneiss of probable Paleozoic age. A nearby hole, Millers Pond test well 1, was logged for geophysical properties.

The GGS drilled the McBean test hole, also known as Burke 5, in 1991 and formally designated it as GGS-3757 (Summerour and others, 1994; Huddlestun and Summerour, 1996). The drill site is near the community of McBean in Burke County, Ga., at lat $33^{\circ} 13^{\prime} 38^{\prime \prime}$ N., long $81^{\circ} 55^{\prime} 50^{\prime \prime} \mathrm{W}$. (fig. 1) and has a land surface elevation of $297 \mathrm{ft}$. The test hole was drilled from land surface to a total depth of $327 \mathrm{ft}$ and terminated in the upper part of the Upper Cretaceous section.

Stratigraphic tops, stratigraphic details, and samples for paleontologic analysis in this volume are reported as core depth below land surface. Geophysical logs for the Millhaven, Girard, and Millers Pond test holes were adjusted slightly to match core depth.

\section{PREVIOUS WORK}

Previous reports on the geology of Burke and Screven Counties and adjacent areas of Georgia include those by Veatch and Stephenson (1911), Brantley (1916), Cooke and Shearer (1918), Cooke (1943), LaMoreaux (1946a,b), LeGrand and Furcon (1956), Herrick (1960, 1961, 1964, 1972), Herrick and Vorhis (1963), Herrick and Counts (1968), Bechtel Corporation (1972, 1973), Carver (1972), Buie (1978), Huddlestun and Hetrick (1978, 1979, 1986, 1991), Prowell and O'Connors (1978), Schroder (1982), McClelland (1987), Huddlestun (1988, 1992), Hetrick (1992), Clarke and others (1994, 1996), Huddlestun and Summerour (1996), Leeth and Nagle (1996), Leeth and others (1996), and Falls and others (1997). Geologic reports on Burke and Screven Counties and adjacent parts of South Carolina include those by Snipes (1965); Hurst and others (1966); Scrudato and Bond (1972); Daniels (1974); Marine and Siple (1974); Bechtel Corporation (1982); Faye and Prowell (1982); Huddlestun (1982); Prowell, Christopher, and others (1985); Colquhoun (1991, 1992); Edwards (1992); Fallaw and Price (1992, 1995); Harris and Zullo (1992); and Prowell (1994). Geologic reports on adjacent parts of South Carolina include those by Sloan (1908); Cooke (1936); Cooke and MacNeil (1952); Christl (1964); Siple (1967); Marine (1979); Smith (1979); Nystrom and Willoughby (1982); Zullo and others (1982); Colquhoun and others (1983); Bledsoe (1984, 1987, 1988); Colquhoun and Steele (1985); Steele (1985); Prowell, Edwards, and Frederiksen (1985); Nystrom and others (1986, 1991); Dennehy and others (1989); Logan and Euler (1989); Robertson (1990); Colquhoun and Muthig (1991); Price and others (1991); Fallaw and others (1992a,b); Snipes and others (1993); and Gellici and others (1995).

\section{ACKNOWLEDGMENTS}

The authors thank the U.S. Department of Energy for its support of this investigation. They also thank the Georgia Geologic Survey for allowing access to the Millers Pond core, and Paul F. Huddlestun for sampling and providing lithologic descriptions of the Thompson Oak and McBean cores. The authors also acknowledge the efforts of Donald G. Queen, Eugene F. Cobbs, and Gerald E. Idler during the coring and logging of the Millhaven and Girard sites.

\section{STRATIGRAPHIC FRAMEWORK}

Lithologic data from the Millhaven, Girard, and Millers Pond cores and geophysical logs from the three associated test holes were used to define the four Cretaceous and five Tertiary units in this study (fig. 2). Correlation of these geologic units in the Millhaven, Girard, and Millers Pond cores is presented in a dip-oriented cross section (fig. 6). 


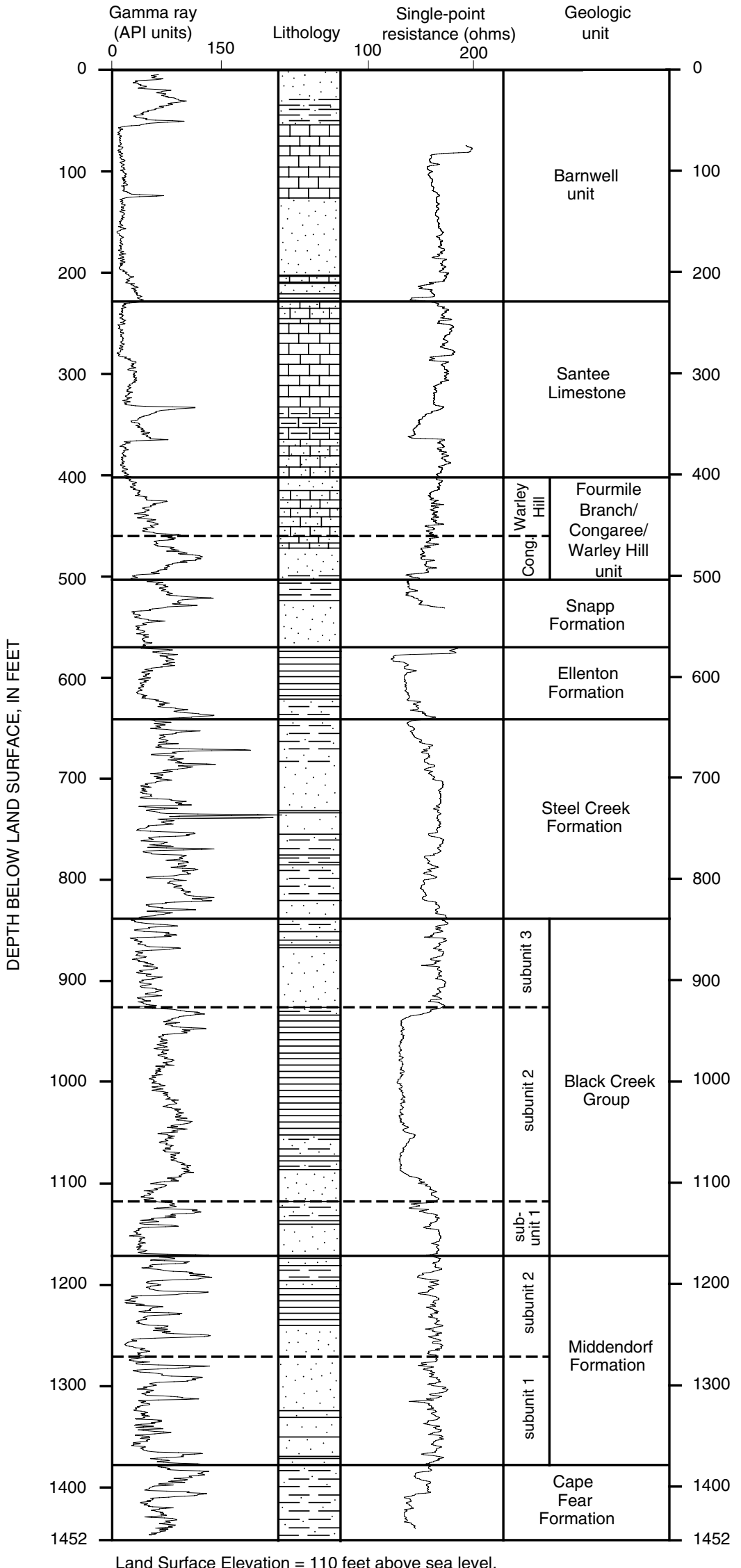

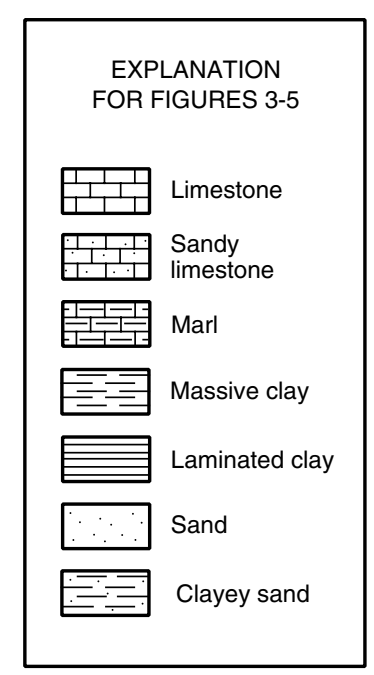

Figure 3. Gamma-ray, single-point resistance, and lithologic $\log$ s and geologic units of the Millhaven test hole in Screven County, Ga. Abbreviation used: API, American Petroleum Institute. 


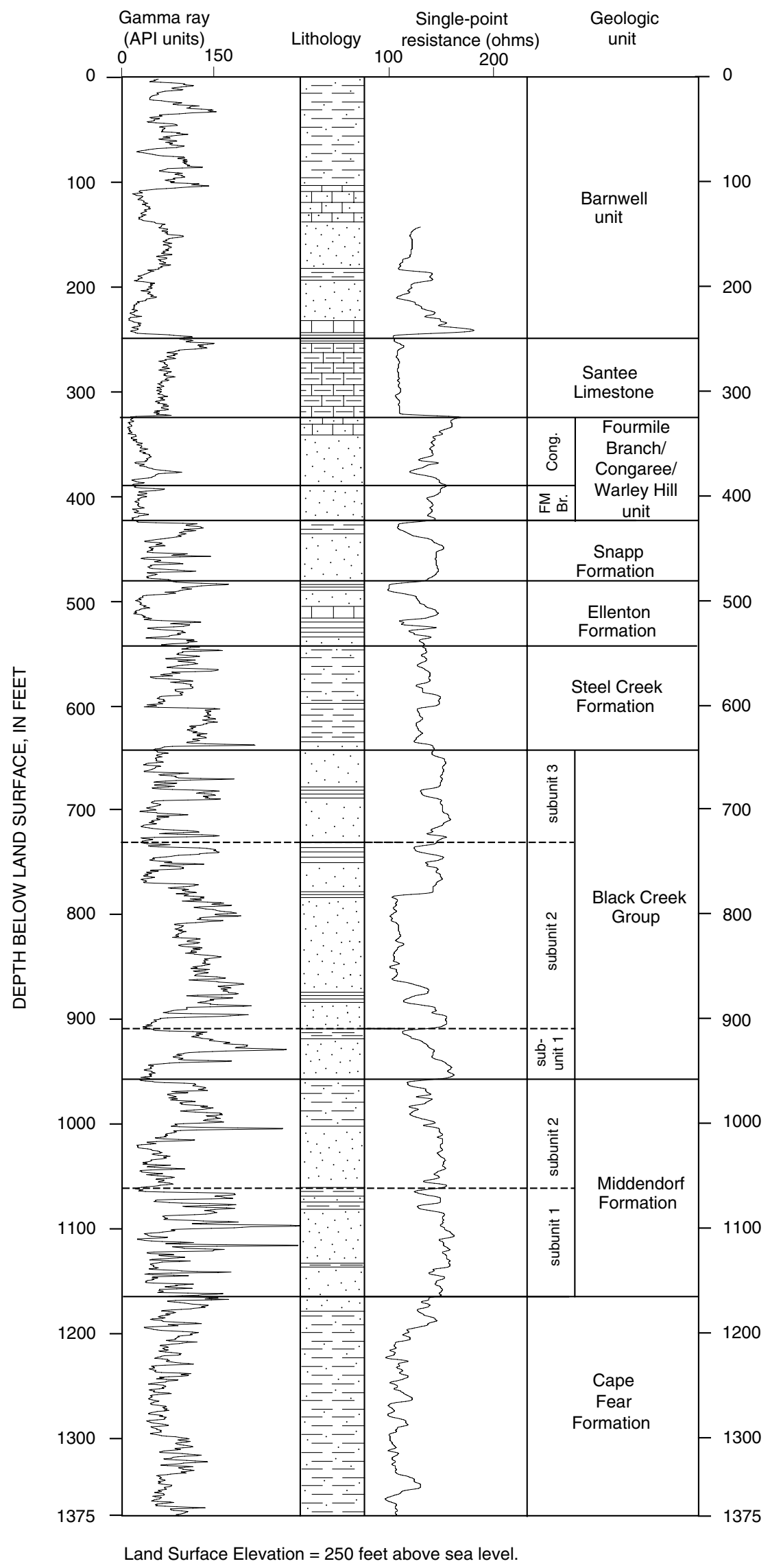

Figure 4. Gamma-ray, single-point resistance, and lithologic logs and geologic units of the Girard test hole in Burke County, Ga. Abbreviation used: API, American Petroleum Institute. Lithologic patterns are explained in figure 3.

Land Surface Elevation = 250 feet above sea level. 


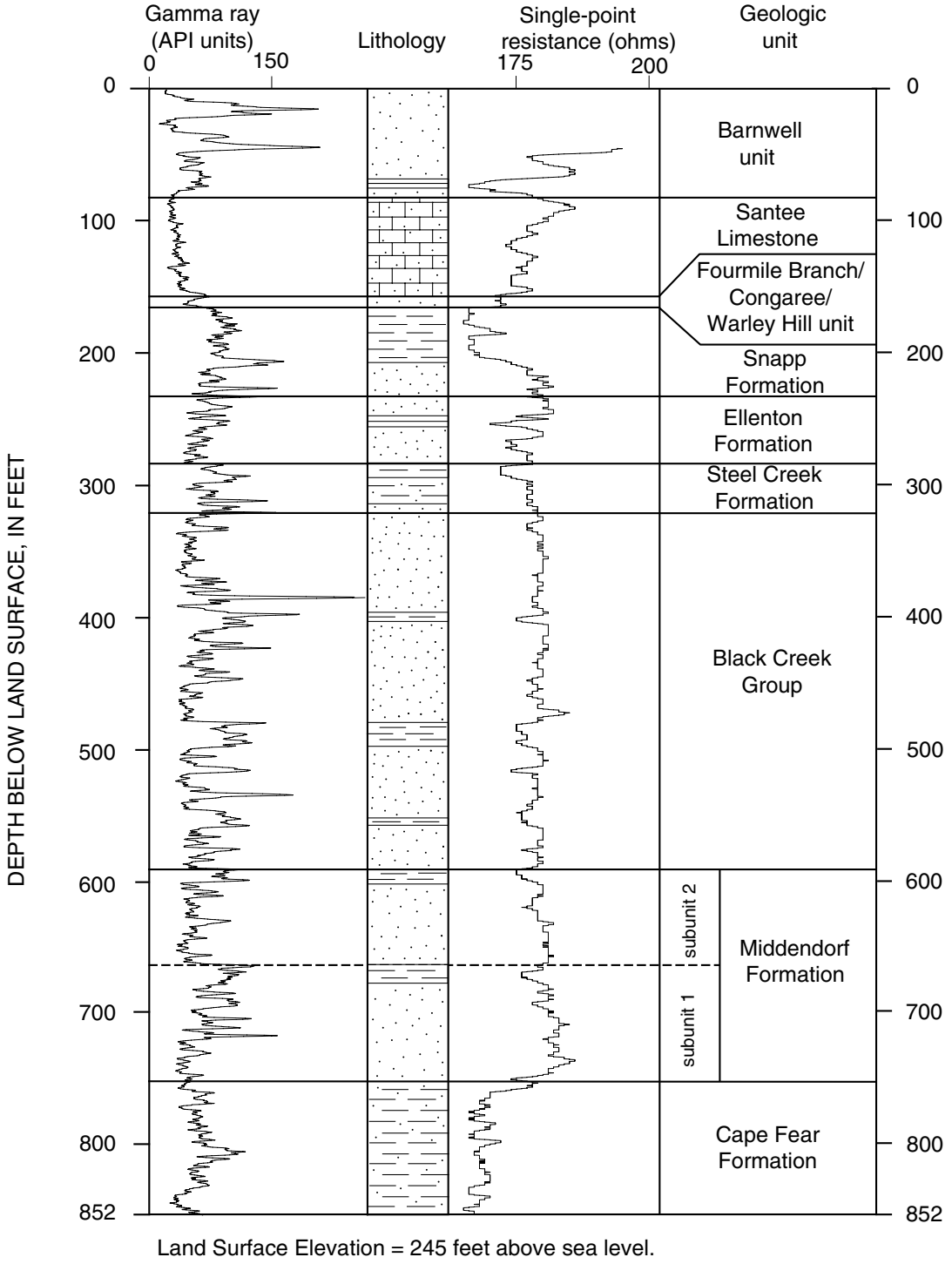

Figure 5. Gamma-ray, single-point resistance, and lithologic logs and geologic units of the Millers Pond test well 1 and test hole in Burke County, Ga. Abbreviation used: API, American Petroleum Institute. Lithologic patterns are explained in figure 3 .
The section roughly parallels the Savannah River and reflects the thicknesses and stratigraphy of the geologic units from the updip Millers Pond site to the downdip Millhaven site. Datum for the section is sea level. The elevation and depth of the stratigraphic top of each geologic unit in these three cores and the Thompson Oak and McBean cores are listed in table 1.

Prowell, Christopher, and others (1985) correlated Cretaceous and Tertiary geologic units in the updip coastal plain from central Georgia to western South Carolina. They identified five of the six Upper Cretaceous units, two Paleocene units, six of the eight Eocene units, and one Oligocene unit in a South Carolina drill hole at the SRS (fig. 2). Their units were essentially chronostratigraphic units that were assigned alpha-numeric designations because of a lack of existing nomenclature. Subsequently, Fallaw and Price (1995) established a working nomenclature and described the stratigraphic units beneath the SRS. The stratigraphy and nomenclature used in this report result from combining information from these reports.

Huddlestun and Hetrick (1991), Summerour and others (1994), and Huddlestun and Summerour (1996) proposed a stratigraphic nomenclature for the updip part of the study area in east-central Georgia. A comparison of the stratigraphic units for previous studies with the stratigraphy in this study is shown in figure 2. The stratigraphy of the Millhaven, Girard, and Millers Pond cores is shown in figures 3, 4 , and 5.

\section{CRETACEOUS STRATIGRAPHY}

The Cretaceous sediments in the study area are divided into the Cape Fear Formation, the Middendorf Formation, the Black Creek Group, and the Steel Creek Formation (fig. 2 ). These four geologic units consist of siliciclastic sediments, are coarser grained and more oxidized in updip 
A8

GEOLOGY AND PALEONTOLOGY OF FIVE CORES FROM SCREVEN AND BURKE COUNTIES, GEORGIA

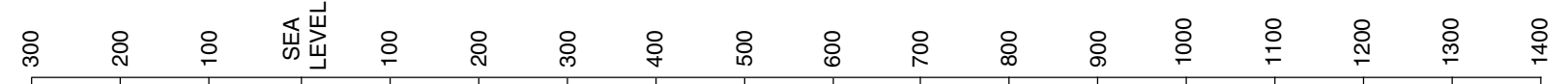

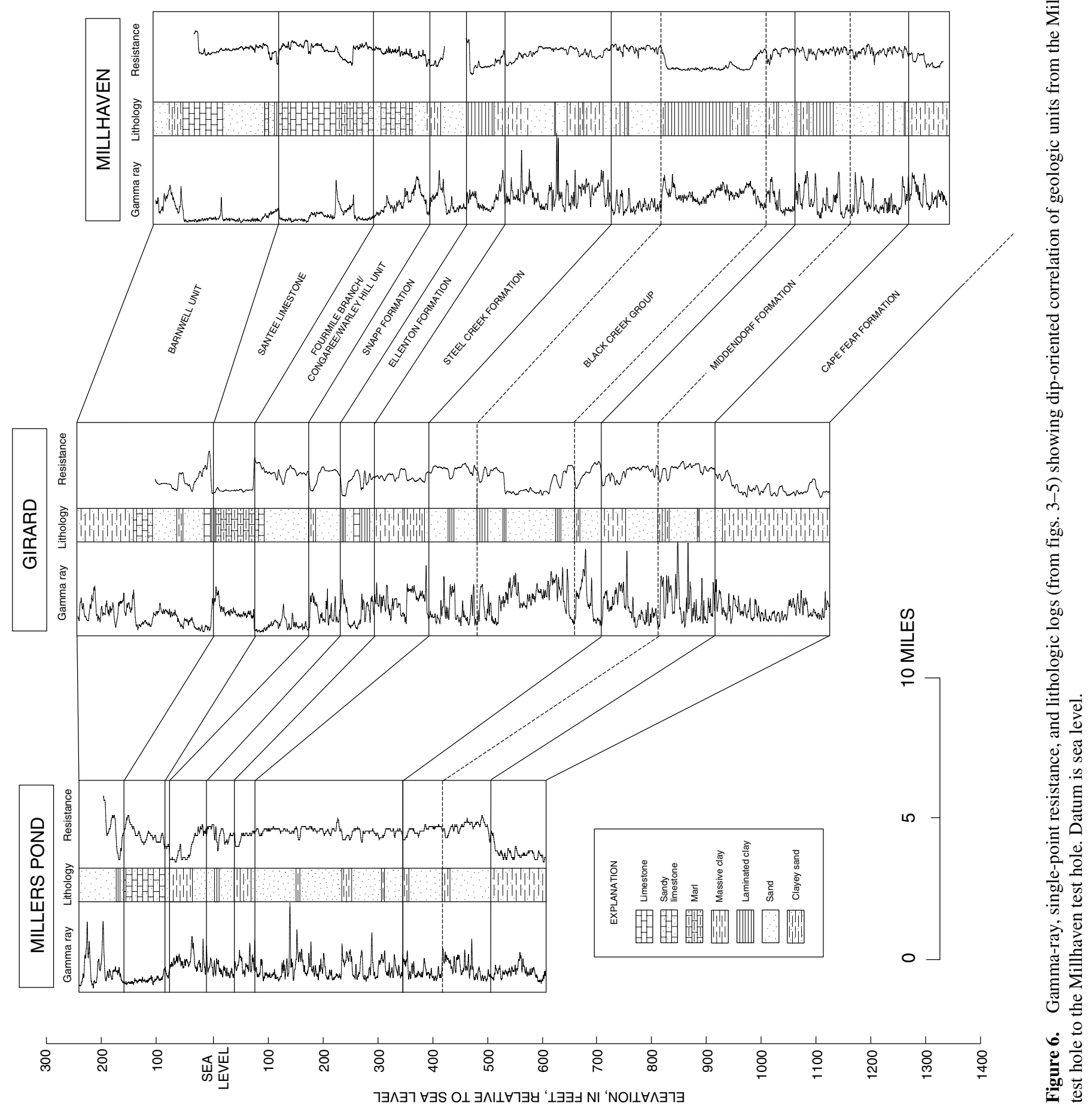


Table 1. Elevations and depths of stratigraphic tops for geologic units and subunits in the Millhaven, Girard, Thompson Oak, Millers Pond, and McBean cores.

[The stratigraphic contacts in the Thompson Oak and the McBean cores are interpreted from lithologic descriptions provided by Paul F. Huddlestun, Georgia Geologic Survey, Atlanta, Georgia. The stratigraphic contacts and names for the Thompson Oak and McBean cores in this table represent the stratigraphic interpretations of the authors and do not agree with Huddlestun's interpretations in all cases. Elevations are in feet above or below sea level. Depths are in feet below land surface. Top of Barnwell unit equals land surface in each core. N.D., not determined; N.P., not penetrated]

\begin{tabular}{|c|c|c|c|c|c|}
\hline \multirow{2}{*}{ Name of geologic unit } & \multicolumn{5}{|c|}{ Elevation/depth of stratigraphic contact } \\
\hline & $\begin{array}{l}\text { Millhaven } \\
\text { core }\end{array}$ & $\begin{array}{l}\text { Girard } \\
\text { core }\end{array}$ & $\begin{array}{c}\text { Thompson Oak } \\
\text { core }\end{array}$ & $\begin{array}{l}\text { Millers Pond } \\
\text { core }\end{array}$ & $\begin{array}{c}\text { McBean } \\
\text { core }\end{array}$ \\
\hline Barnwell unit--------------------------------------- & $110 / 0$ & $250 / 0$ & $240 / 0$ & $245 / 0$ & $297 / 0$ \\
\hline 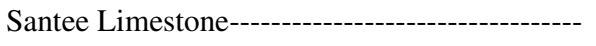 & $-118 / 228$ & $0 / 250$ & $110 / 130$ & $163 / 82$ & $185 / 112$ \\
\hline Fourmile Branch/Congaree/ Warley Hill unit - & $-291 / 401$ & $-75 / 325$ & $58 / 182$ & $89 / 156$ & $111 / 186$ \\
\hline Warley Hill Formation -------------------- & $-291 / 401$ & absent & absent & absent & absent \\
\hline Congaree Formation ------------ & $-352 / 462$ & $-75 / 325$ & $58 / 182$ & $89 / 156$ & $111 / 186$ \\
\hline Fourmile Branch Formation -------------- & absent & $-140 / 390$ & $-11 / 251$ & absent & absent \\
\hline 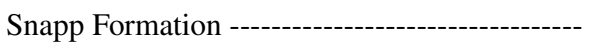 & $-394 / 504$ & $-173 / 423$ & absent & $80 / 165$ & $75 / 222$ \\
\hline Ellenton Formation-------. & $-460 / 570$ & $-231 / 481$ & $-34 / 274$ & $13 / 232$ & $25 / 272$ \\
\hline Steel Creek Formation -------------------- & $-532 / 642$ & $-292 / 542$ & $-84 / 324$ & $-39 / 284$ & $-8 / 305$ \\
\hline 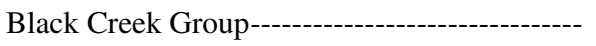 & $-729 / 839$ & $-392 / 642$ & $-166 / 406$ & $-87 / 322$ & N.P. \\
\hline Subunit 3 -------- & $-729 / 839$ & $-392 / 642$ & $-166 / 406$ & $-87 / 322$ & N.P. \\
\hline Subunit 2 ------------ & $-817 / 927$ & $-482 / 733$ & N.D. & N.D. & N.P. \\
\hline Subunit 1 ----------------------------------- & $-1,009 / 1,119$ & $-659 / 909$ & N.D. & N.D. & N.P. \\
\hline Middendorf Formation ------------------------ & $-1,062 / 1,172$ & $-708 / 958$ & $-445 / 685$ & $-347 / 592$ & N.P. \\
\hline Subunit 2 ------------------------------------ & $-1,062 / 1,172$ & $-708 / 958$ & $-445 / 685$ & $-347 / 592$ & N.P. \\
\hline 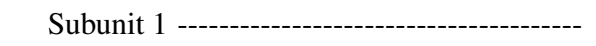 & $-1,162 / 1,272$ & $-812 / 1,062$ & $-485 / 725$ & $-418 / 663$ & N.P. \\
\hline 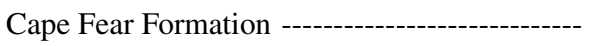 & $-1,269 / 1,379$ & $-913 / 1,163$ & $-602 / 842$ & $-507 / 752$ & N.P. \\
\hline 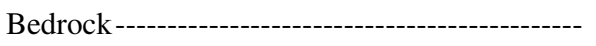 & N.P. & $-1,125 / 1,375$ & $-756 / 996$ & $-603 / 852$ & N.P. \\
\hline
\end{tabular}

areas, and become finer grained in a coastward direction. Unit contacts are typically overlain by lags of very poorly sorted sand containing granules, pebbles, and lithoclasts. Each contact is considered to be a regional unconformity and probably denotes a considerable hiatus in sedimentation. In the updip area, lithologic similarities among the units and the presence of only a few fossil-bearing beds make it difficult to identify unit contacts at Millers Pond. Evidence of possible unconformities is used to divide the Middendorf Formation into two subunits in the Millhaven, Girard, and Millers Pond cores, and the Black Creek Group into three subunits in the Millhaven and Girard cores. Prowell, Christopher, and others (1985) identified units UK1 through UK6 in their study but did not correlate their unit UK3 with units in the test holes at the SRS.

Biostratigraphic studies by Christopher (1978) and Prowell, Christopher, and others (1985) suggested that Cretaceous strata in east-central Georgia ranged in age from Coniacian to Maastrichtian. The sediments in the four units have been interpreted as parts of large deltaic systems that prograded across the paleo-continental shelf in east-central Georgia and western South Carolina (Prowell and others, 1985a; Fallaw and Price, 1995). Lithofacies observed in the Upper Cretaceous units accumulated in coarser grained proximal and finer grained distal deltaic settings.

\section{CAPE FEAR FORMATION}

The Cape Fear Formation consists of partially lithified to unlithified, poorly to very poorly sorted clayey sand and sandy clay with a few beds of silty clay. The sand is fine to very coarse with granules and pebbles and is predominantly angular to subangular quartz with some feldspar. Cristobalite in the clay matrix results in lithologies that are harder and denser than sediments in the other Cretaceous units. The cristobalitic clay matrix imparts a yellowish-green to greenish-gray color to most of the lithologies and occludes most of the intergranular porosity in the sand beds. Electric logs display low resistance in the sands and the clays in most of this unit. Sands in the upper 10 to $20 \mathrm{ft}$ of this unit in the Millhaven and Girard cores are unlithified and have atypically high resistance values on the electric logs.

The Cape Fear Formation contains multiple finingupward cycles that range in thickness from 3 to $15 \mathrm{ft}$. Each cycle grades upward from a basal coarse pebbly sand to clayey sand or clay. The clays are oxidized and are generally stained with reddish-brown and yellowish-brown patches of iron oxide. A root-trace pattern is present at the top of a few of the fining-upward cycles and at the top of this unit in the Millhaven core. Sediments directly beneath the upper contact of the Cape Fear Formation in the other cores are 
stained with iron oxides. Lag deposits at the base of the Cape Fear Formation contain clasts of saprolitic gneiss in the Millers Pond core and clasts of Triassic siltstone in the Girard core.

Most of the strata in this unit are barren of fossils, but a few samples of gray and olive-gray, silty clay from the Millers Pond core yielded low-abundance and low-diversity pollen assemblages. Palynologic analysis of these samples from the Millers Pond core (Frederiksen and others, this volume, chap. C) indicates a Coniacian microflora that is consistent with the microflora of the Cape Fear Formation of South Carolina and North Carolina (Christopher and others, 1979; Christopher, 1982; Sohl and Owens, 1991). Prowell, Christopher, and others (1985) and Fallaw and Price (1995) suggested a Santonian age for unit UK1 and the Cape Fear Formation at the SRS. Huddlestun and Summerour (1996) suggested that the Cape Fear Formation is equivalent to the Cenomanian-Turonian Tuscaloosa Formation of western Georgia. Samples from this formation were not processed for the other cores.

The presence of a terrestrial microflora and the absence of dinoflagellates and other marine fossils in the Cape Fear Formation suggest deposition in a nonmarine environment at Millers Pond. The Cape Fear Formation in the Millhaven and Girard cores is lithologically similar to the section in the Millers Pond core and also is interpreted as having been deposited in a nonmarine environment. The multiple fining-upward cycles, the coarse texture of the sands, the iron-oxide staining, and root-trace patterns in the clays suggest that most of this unit was deposited in channel and overbank environments during aggradation of a fluvially dominated, subaerially exposed part of a delta-plain environment.

\section{MIDDENDORF FORMATION}

The Middendorf Formation consists predominantly of unlithified sand, which is locally fine to very coarse or fine to medium quartz (figs. 3, 4, 5). The sand includes smoky-quartz granules and pebbles, mica, lignite, and generally very little clay matrix. The Middendorf sands are moderately to poorly sorted and are very porous and permeable in comparison with the sands in the underlying Cape Fear Formation. Black clay is present in laminae and thin beds that are less than $2 \mathrm{ft}$ thick in the Millhaven core. Clay beds in the Millers Pond core and most of the Girard core generally are light gray to white and range in thickness from 1 to $10 \mathrm{ft}$.

The Middendorf Formation contains two distinct subunits in the Millhaven, Girard, and Millers Pond cores. Additional work in the study area may show these subunits to be separate, mappable formations. At present, they are informally referred to in ascending order as subunits 1 and 2 of the Middendorf Formation. Each subunit includes a basal lag deposit of poorly sorted sand that grades up to interbedded and interlaminated clay and sand. Micaceous and lignitic sand laminae are common in the Middendorf sections, particularly near the top of each subunit. Clay beds are generally thicker and display more abundant iron-oxide staining near the top of each subunit in the Millers Pond and Girard cores. A root-trace pattern is observed in the clay at the top of subunit 2 in the Girard core. Clays at the top of each subunit in the Millhaven core are not stained with iron oxides.

Lithologic data and geophysical log patterns seem to indicate that the upper contact of the Middendorf Formation in the Georgia cores correlates with the unit UK2/UK4 boundary of Prowell, Christopher, and others (1985) and the top of the Middendorf Formation as recognized by Fallaw and Price (1995) at the SRS. A Santonian age was reported for unit UK2 by Prowell, Christopher, and others (1985) and for the Middendorf Formation at the SRS by Fallaw and Price (1995). Samples collected at 1,138 and 1,012 ft in the Girard core and $1,212 \mathrm{ft}$ in the Millhaven core contain pollen that suggests at least part of the Middendorf Formation may be correlative with the Shepherd Grove Formation, which overlies the Middendorf in South Carolina (Frederiksen and others, this volume, chap. C).

All or part of what has been described as Middendorf Formation in this part of Georgia may actually be correlative with part of the Black Creek Group or an updip lithofacies of either the Caddin or Shepherd Grove Formations, which Gohn (1992) identified as late Santonian to early Campanian in age. Evidence of subaerial exposure and erosional lags at the contacts between the upper and lower subunits support the possibility that unit UK2 (Prowell, Christopher, and others, 1985), as defined beneath the southeastern corner of the SRS, contains more than one depositional sequence and is equivalent in part to unit UK3.

Huddlestun and Hetrick (1991) applied the name Pio Nono Formation in updip areas of east-central Georgia to the Middendorf Formation as used here. Dinoflagellates and other marine indicators are sparse and suggest a marginal-marine environment at Millhaven and a nonmarine environment for this unit in the other cores.

\section{BLACK CREEK GROUP}

The Black Creek Group consists of three distinct subunits in the Millhaven and Girard cores: a basal lignitic sand in subunit 1, a laminated black clay and sand in subunit 2 , and a coarsening-upward sand sequence in subunit 3 (figs. 3,4 , table 1). The lag deposits at the bases of the subunits suggest the possibility of unconformities in the Black Creek Group at Millhaven and Girard. The Black Creek Group at Millers Pond is coarser and sandier and is not divided into subunits (fig. 5).

Black Creek subunit 1 consists of moderately to poorly sorted, fine to coarse quartz sand that grades into overlying 
very fine to fine sand with a few thin beds of clay. The sand contains abundant interlaminated fine lignite and mica and very little clay matrix. This subunit is lithologically very similar to the underlying Middendorf Formation.

Black Creek subunit 2 in the Millhaven core has a sharp basal contact at $1,119 \mathrm{ft}$ and a second sharp contact at $1,099 \mathrm{ft}$. Each contact is overlain by a basal lag deposit of very poorly sorted sand. The sand above the contact at 1,099 $\mathrm{ft}$ grades and fines into an overlying 161-ft section of predominantly silty laminated black clay. The 161-ft clay section also includes very fine to fine sand from 1,063 to $1,051 \mathrm{ft}$. Most of subunit 2 is calcareous and contains laminae and lenses of very fine sand and sand-filled burrows. Very fine to fine sand is interlaminated at the top of the clay from 934 to $927 \mathrm{ft}$. Subunit 2 in the Girard core is sandier and consists of very fine to fine sand with interbedded black clay. The sand at Millhaven and Girard includes mica, lignite, and minor amounts of glauconite.

Bioturbation features in subunit 2 at Millhaven and Girard include clay-lined burrows, mottled textures, and discontinuous laminae of clay in the sands. Subunit 2 at Millhaven and Girard yielded the most abundant and diverse marine macrofaunas and microfaunas and microfloras in the Cretaceous section in the study area, including shark teeth, pelecypods, ostracodes, benthic and planktonic foraminifers, spicules, dinoflagellates, pollen, and calcareous nannofossils (Bukry, this volume, chap. D; Frederiksen and others, this volume, chap. C; Gohn, this volume, chap. E).

Black Creek subunit 3 in the Millhaven core is a coarsening-upward sequence and consists of a very poorly sorted lag deposit from 927 to $926 \mathrm{ft}$; moderately to well-sorted, very fine to medium sand from 926 to $880 \mathrm{ft}$; and moderately sorted, fine to coarse sand from 880 to $826 \mathrm{ft}$. This subunit at Millhaven includes laminae and thin beds of dark-gray clay, large and small pieces of lignite, and mica; the subunit is crossbedded from 907 to $900 \mathrm{ft}$.

Black Creek subunit 3 in the Girard core has a sharp basal contact at $733 \mathrm{ft}$ and a lag deposit of very poorly sorted sand and granules from 733 to $730 \mathrm{ft}$. The section includes beds of moderately to poorly sorted, medium to very coarse sand; and moderately sorted, fine to medium sand with 5 to 10 percent clay matrix. This section is crossbedded from 714 to $710 \mathrm{ft}$ and 679 to $660 \mathrm{ft}$ and includes one light-gray, iron-stained clay from 685 to $679 \mathrm{ft}$. The top of the clay at $679 \mathrm{ft}$ is overlain by a lag deposit of very poorly sorted sand and granules.

The Black Creek Group at Millers Pond contains poorly sorted, fine to very coarse sand and beds of clay (fig. 5). Granules and pebbles are more abundant and form several very poorly sorted lags at the base of sand beds, which generally include clay clasts. The sand is unlithified and has minor amounts of clay matrix. The tops of clay beds generally are stained with yellow and red iron oxides.

Paleontologic data from the studied cores suggest a Campanian age for the Black Creek Group (Frederiksen and others, this volume, chap. C; Bukry, this volume, chap. D; Gohn, this volume, chap. E). Units UK4 and UK5 (Prowell, Christopher, and others, 1985) and the Black Creek Group at the SRS (Fallaw and Price, 1995) are assigned an age of Campanian to Maastrichtian. Huddlestun and Hetrick (1991) applied the name Gaillard Formation to the fluvial lithofacies in the updip Georgia Coastal Plain. Paleontologic data (Frederiksen and others, this volume, chap. C; Bukry, this volume, chap. D; Gohn, this volume, chap. E) suggest that the calcareous lithologies of subunit 2 at Millhaven are equivalent to the Donoho Creek Formation of the Black Creek Group (Owens, 1989; Sohl and Owens, 1991).

The diversity and abundance of dinoflagellates, the abundance of marine faunas, and the presence of glauconite at Millhaven and Girard suggest a strong marine influence during the deposition of subunit 2, probably in the distal part of a deltaic complex. Dinoflagellates in subunit 3 suggest a marginal-marine depositional environment. The composition of the microflora and the absence of other marine indicators suggest that subunit 1 at Millhaven and Girard and the entire section of the Black Creek Group at Millers Pond reflect sedimentation in a nonmarine part of the delta (Frederiksen and others, this volume, chap. C).

\section{STEEL CREEK FORMATION}

Most of the Steel Creek Formation in the Georgia test holes consists of poorly to very poorly sorted, fine to very coarse sand with granules and pebbles of smoky quartz and 5 to 15 percent clay matrix (figs. $3,4,5$ ). The basal lags are overlain by thick intervals of oxidized clay in the Millhaven and Girard cores. Steel Creek sections include multiple fining-upward sequences with beds of coarser grained sand that become finer and grade into overlying clay beds. Many of the clay beds are stained with iron oxide and contain as much as 40 percent sand by volume. Root traces typically are present at the top of the thick oxidized clay near the base of the section and in some of the clay beds near the top of this unit. Crossbedding is common at Millhaven. Lignite and mica are common accessory constituents.

Kidd (1996) used a subtle difference in grain size and clay content and geophysical-log correlations with test holes on the SRS to identify the contact between the Black Creek Group and the Steel Creek Formation at $397 \mathrm{ft}$ in the Millers Pond core. Huddlestun and Summerour (1996) identified the basal contact at $367 \mathrm{ft}$ in the Millers Pond core and 414 $\mathrm{ft}$ in the Thompson Oak core; they described the contact between the Black Creek (Gaillard) and Steel Creek Formations as either conformable or paraconformable in updip parts of Burke County and as gradational in the Girard core. The contact between the Black Creek Group and the Steel Creek Formation is recognized as an unconformity at the Millhaven and Girard sites. This boundary is placed at the sharp contact at $322 \mathrm{ft}$ in the Millers Pond core in this report 
on the basis of projecting the contact from the downdip Girard core.

Most of the sediments in the Steel Creek Formation are barren of fossils. Thin beds of brownish-gray clay in the Steel Creek section of the Millhaven core yielded Cretaceous and Paleocene palynomorphs, but more diagnostic taxa were not recovered (Frederiksen and others, this volume, chap. C). The presence of dinoflagellates and Paleocene palynomorphs in samples collected from the Steel Creek section in the Millhaven core is discounted as contamination of the samples with drilling mud (Edwards and others, this volume, chap. B). Paleontologic data from the underlying Black Creek Group and the overlying Ellenton Formation restrict the age of the Steel Creek Formation to the Maastrichtian.

Prowell, Christopher, and others (1985) identified a correlative section in wells at the SRS as middle Maastrichtian in age and designated it as unit UK6. They considered unit UK6 to be a biostratigraphic equivalent of the Providence Sand and part of the Ripley Formation in Georgia and the Peedee Formation in eastern South Carolina (fig. 2). Fallaw and Price (1995) described and named the Steel Creek Formation at the SRS. Huddlestun and Summerour (1996) also applied the name Steel Creek Formation to cored sections in east-central Georgia and considered the Steel Creek Formation to be early Maastrichtian.

Marine fossils, carbonate minerals, and glauconite are absent from the Steel Creek sections of the studied cores. The coarse sediments, fining-upward sequences, indications of rooting, and iron-oxide staining suggest channel and overbank deposits in a delta-plain environment.

\section{TERTIARY STRATIGRAPHY}

The Tertiary section in this report includes the Ellenton and Snapp Formations in the Paleocene strata and the Fourmile Branch/Congaree/Warley Hill unit, the Santee Limestone, and the Barnwell unit in the Eocene and younger strata (fig. 2). Each of the Eocene units in the Georgia cores can be lithologically, geophysically, or biostratigraphically correlated with more than one formal formation in the study area and is informally named in the report.

The stratigraphy proposed by Prowell, Christopher, and others (1985) at the southeastern corner of the SRS included two Paleocene units designated as units P1 and P2, six Eocene units designated as units E1, E3, E4, E5, E7, and $\mathrm{E} 8$, and an Oligocene unit designated as unit O1. Units E2, E6, and M1 were recognized and correlated in Georgia but were not correlated with units in the southeastern corner of the SRS (Prowell, Christopher, and others, 1985).

\section{ELLENTON FORMATION}

The Ellenton Formation in the Georgia cores is finer grained, calcareous, and very glauconitic in the downdip Millhaven and Girard cores. It is coarser grained and noncalcareous in the updip Millers Pond core (fig. 6). Lag deposits and sharp bedding contacts identify basal unconformities and possible unconformities within the Georgia sections.

The Ellenton Formation in the Millhaven core consists of glauconitic, calcareous, fine to coarse sand and laminated clay from 642 to $622 \mathrm{ft}$; well-laminated, slightly calcareous, silty black clay from 622 to $595 \mathrm{ft}$; and calcareous to noncalcareous clay from 595 to $570 \mathrm{ft}$ (fig. 3). The Ellenton Formation in the Girard core consists of noncalcareous sand and black clay from 542 to $518 \mathrm{ft}$; sandy carbonate and limestone and calcareous sand with abundant glauconite from 518 to $491 \mathrm{ft}$; and well-laminated, noncalcareous silty clay from 491 to $481 \mathrm{ft}$ (fig. 4). The section generally contains well-sorted, fine to medium quartz sand. The lag deposits at 638, 625, and $595 \mathrm{ft}$ in the Millhaven core and $518 \mathrm{ft}$ in the Girard core contain 10 to 20 percent glauconite, several rounded phosphatic clasts, and shark teeth. A high-angle shear defines a sharp contact at $491 \mathrm{ft}$ in the Girard core.

The Ellenton Formation in the updip Millers Pond core consists of fine to very coarse sand with interbedded sandy clay from 284 to $263 \mathrm{ft}$; interlaminated black lignitic clay and very fine to medium sand from 263 to $247 \mathrm{ft}$; and fine to medium clayey sand from 247 to $232 \mathrm{ft}$ (fig. 5). The laminated black clay is very dense and may contain as much as 5 percent mica. Recovery of sediment in the Millers Pond core was not as good as recovery in the Millhaven and Girard cores; however, poorly sorted pebble lag deposits at 284 and $271 \mathrm{ft}$ and clay clasts at 263 and $244 \mathrm{ft}$ suggest possible unconformities and reworking of the Ellenton Formation in the Millers Pond core.

Paleontologic results suggest that the Ellenton Formation in this report is equivalent to unit P1 (Prowell, Christopher, and others, 1985) and the Ellenton Formation in South Carolina (Prowell, Edwards, and Frederiksen, 1985). Huddlestun and Summerour (1996) described a unit that they identified as the Black Mingo Formation undifferentiated in Georgia. They recognized a lower and an upper unit that resemble lithologies of the Rhems, Williamsburg, and Lang Syne Formations of the Black Mingo Group (Van Nieuwenhuise and Colquhoun, 1982). Fallaw and Price (1995) divided the Ellenton section into the Sawdust Landing and Lang Syne Formations in wells near the southeastern border of the SRS. The noncalcareous, nonglauconitic sand and clay from 542 to $518 \mathrm{ft}$ at Girard and from 284 to $263 \mathrm{ft}$ at Millers Pond are lithologically similar to the Sawdust Landing Formation. However, a similar lithologic unit was not recognized at Millhaven. The rest of the Ellenton Formation at Millhaven and Girard is similar to the very glauconitic 
and silty lithologies of the Lang Syne Formation. The carbonate component at Millhaven and Girard is not described in the Lang Syne Formation at the SRS but is described as part of this unit beneath Allendale County in South Carolina (Fallaw and Price, 1995; Gellici and others, 1995).

Paleontologic studies identified a diverse microflora of dinoflagellates, pollen, and calcareous nannofossils and a faunal component of ostacodes, planktonic foraminifers, pelecypods, and gastropods in the downdip sections (Edwards and others, this volume, chap. B). The updip section at Millers Pond contains a low-diversity microflora of dinoflagellates and pollen (Clarke and others, 1994). The marine fossils, glauconite, and carbonate in downdip sediments indicate an open-marine environment, possibly distal prodelta. The low diversity and the low abundance of dinoflagellates and the absence of other marine indicators at Millers Pond suggest a change to a more restricted marginal-marine environment.

\section{SNAPP FORMATION}

The Snapp Formation at Millhaven, Girard, and Millers Pond consists of moderately to poorly sorted, fine to very coarse sand overlain by iron-stained, oxidized kaolin (figs. 3, 4, 5). The sand is unlithified and generally has granules, pebbles, and less than 10 percent clay matrix. Individual sand beds typically are coarse to very coarse in the lower part of each section. In the middle of each section, the sand beds are fine to medium. At the top of each section, the sand beds grade into white to very light gray kaolin. The clay is stained with red and yellow iron oxides. Pedogenic structures in the otherwise massive clay include root traces and desiccation cracks. Pyrite is disseminated in the clay and along desiccation cracks near the top of the Snapp Formation in the Millers Pond and Girard cores.

The Snapp Formation in Georgia is equivalent to unit P2 (Prowell, Christopher, and others, 1985) and the Snapp Formation at the SRS (Fallaw and Price, 1995). McClelland (1987) applied the name Rhems Formation (lower Paleocene part of the Black Mingo Group) to a combined section of the Snapp and Ellenton Formations in upper Burke County. The Snapp Formation holds the same upper Paleocene stratigraphic position as the Chicora Member of the Williamsburg Formation of the Black Mingo Group (Van Nieuwenhuise and Colquhoun, 1982). The Snapp Formation in the Georgia cores and in cores on the SRS (Fallaw and Price, 1995) is lithologically different from the marine sediment of the Chicora Member.

The Snapp Formation is absent from the Thompson Oak core (fig. 1, table 1). Fallaw and Price (1995) described an updip limit for the Snapp Formation near the Upper Three Runs Creek in Aiken County, S.C. Extension of this boundary into Georgia would place the Thompson Oak core near the updip limit of the Snapp Formation. The presence of Snapp sediments in the McBean core indicates that the updip limit is irregular in that it trends to the northwest from the Thompson Oak test hole across the northern part of Burke County, Ga. (fig. 1).

Paleontologic samples were not collected from the Snapp Formation in the Girard and Millers Pond cores because of the extensive oxidation of the sediments. A sample from the base of this formation in the Millhaven core yielded sparse dinoflagellates that are not age diagnostic (Edwards and others, this volume, chap. B). The stratigraphic position of this unit between the Ellenton Formation and the overlying early Eocene part of the Fourmile Branch/Congaree/Warley Hill unit suggests that the age of the strata is either late Paleocene (Prowell, Christopher, and others, 1985; Fallaw and Price, 1995) or early Eocene (Harris and Zullo, 1992). Paleontologic data from a sample at $264 \mathrm{ft}$ in the McBean core indicated a Paleocene age; however, the authors have not independently verified that the sample at $264 \mathrm{ft}$ is from the Snapp Formation. This sample of the McBean core is above the base of the Snapp Formation as selected by Huddlestun and Summerour (1996).

Sedimentary characteristics suggest a fluvially dominated depositional environment in either an upper delta plain or an incised alluvial valley. The presence of dinoflagellates in the Millhaven core suggests a marginal-marine environment in the downdip part of the study area. The Snapp Formation at Girard is $58 \mathrm{ft}$ thick, which is roughly $20 \mathrm{ft}$ thicker than the Snapp Formation in cores from the southeastern part of the SRS. The thicker section of the Snapp Formation in the Girard core overlies a section of the Ellenton Formation that is thinner by $20 \mathrm{ft}$ relative to the Ellenton section in the southeastern part of the SRS. Structural-contour and isopach maps of the Black Mingo (Ellenton) and Snapp Formations also indicate thicker sections of the Snapp Formation over thinner sections of the Black Mingo (Ellenton) Formation in eastern Burke County and southern Barnwell County (Huddlestun and Summerour, 1996). This thickness change is interpreted here as evidence of channel incision of the Snapp Formation into the laminated black clay of the Ellenton Formation.

\section{FOURMILE BRANCH/CONGAREE/WARLEY HILL UNIT}

The lithologies of the Fourmile Branch/Congaree/Warley Hill unit range from mixed-siliciclastic-carbonate sections in the central and downdip Georgia cores to siliciclastic sections in the updip cores (figs. 3, 4, 5, 6). Paleontologic data suggest that the strata in this unit are correlative with three formally named formations at the SRS (fig. 2). However, all three formations are not consistently present in each of the Georgia cores (table 1).

In the downdip Millhaven core, the Fourmile Branch/ Congaree/Warley Hill unit consists of interbedded quartz sand, marl, and limestone. The sand is very fine to fine 
below a depth of $415 \mathrm{ft}$ and fine to medium above a depth of $415 \mathrm{ft}$ and is moderately to well sorted throughout. Glauconite is a common accessory mineral and is abundant at 462 ft. The carbonate beds range from lithified to unlithified and include glauconite, clay matrix and fossils. Extensive burrowing is recognized in the sandy carbonate matrix.

In the Girard core, this unit consists of medium to coarse sand from 423 to $390 \mathrm{ft}$; fine to medium sand from 366 to $350 \mathrm{ft}$; and medium to coarse sand, sandy carbonate, and limestone from 342 to $325 \mathrm{ft}$. A large part of the unit from 390 to $366 \mathrm{ft}$ and several other parts of the section were not recovered during coring. The section below $390 \mathrm{ft}$ is predominantly noncalcareous with only trace amounts of glauconite, generally less than 5 percent clay matrix, clay laminae, and clay-lined burrows. Unlithified sandy carbonate and partially lithified calcareous sand are abundant above $366 \mathrm{ft}$.

This unit in the Millers Pond core consists of a 9-ft section of well-sorted, very fine to fine sand. The sand contains less than 5 percent clay matrix, but clay-lined burrows are present.

Surface mapping and drill hole evidence from this updip region in Georgia and adjacent areas of South Carolina indicate a thicker section of sand and clay (Nystrom and Willoughby, 1982; Nystrom and others, 1986; McClelland, 1987; Prowell, 1994). On the basis of data from augered holes that are 1 mile west of the Millers Pond core site, McClelland (1987) described a 40-ft section of the Huber Formation, a time-equivalent lithofacies of the Congaree Formation. In the Huber Formation described by McClelland (1987), the burrowed, fine sand observed at Millers Pond is overlain by a crossbedded, fine to coarse quartz sand and lenticular beds of massive, lignitic kaolinitic clay.

Dinoflagellates, pollen, and calcareous nannofossils were recovered from the core samples of the Fourmile Branch/Congaree/Warley Hill unit at Millhaven and Girard. Dinoflagellates and pollen were recovered from the Thompson Oak and Millers Pond cores. Paleontologic examination of these core samples indicates that this unit is early Eocene to early middle Eocene in age and that it includes more than one biostratigraphic unit (Bybell, this volume, chap. F; Frederiksen, this volume, chap. H; Edwards, this volume, chap. G). Other fossils observed in the Millhaven core included bryozoans, pelecypods, and foraminifers below $462 \mathrm{ft}$ and pelecypods and foraminifers above $462 \mathrm{ft}$. In the Girard core, pelecypods, bryozoans, and shark teeth were observed above $342 \mathrm{ft}$. Biomoldic pores indicate that gastropods also were present.

The Fourmile Branch/Congaree/Warley Hill unit from 423 to $390 \mathrm{ft}$ in the Girard core is lithologically and geophysically correlative with the Fourmile Branch Formation at the SRS (Fallaw and Price, 1995). The age of this part of the Girard core could not be determined from fossil evidence. An early Eocene age was determined with dinoflagellates from samples of the Thompson Oak core from 274 to $251 \mathrm{ft}$ (Edwards, this volume, chap. G). These sections in the Girard and Thompson Oak cores appear to be equivalent to unit E2 of Prowell, Christopher, and others (1985) and the Fourmile Branch Formation at the SRS (Fallaw and Price, 1995). A biostratigraphically correlative section was not identified at Millhaven, Millers Pond, or McBean.

The section from 390 to $325 \mathrm{ft}$ in the Girard core is biostratigraphically correlative with the sections from 504 to $462 \mathrm{ft}$ in the Millhaven core and from 165 to $156 \mathrm{ft}$ in the Millers Pond core, and with samples collected from depths of 210, 194, 192, and $183 \mathrm{ft}$ in the Thompson Oak core. This part of the Fourmile Branch/Congaree/Warley Hill unit is equivalent to unit E3 (Prowell, Christopher, and others, 1985) and the Congaree Formation in South Carolina (Fallaw and Price, 1995) and Georgia (Huddlestun and Summerour, 1996).

The Fourmile Branch/Congaree/Warley Hill section from 462 to $401 \mathrm{ft}$ in the Millhaven core is lithologically equivalent and geophysically correlative with at least part of the Congaree Formation as identified in the subsurface of Allendale County in South Carolina (Gellici and others, 1995). This section is biostratigraphically equivalent to the lower part of unit E4 (Prowell, Christopher, and others, 1985) and the Warley Hill Formation at the SRS (Fallaw and Price, 1995). A biostratigraphic equivalent to this part of the Fourmile Branch/Congaree/Warley Hill section is not identified in the other studied cores in Georgia.

Sedimentary characteristics of the Fourmile Branch sections in the Girard and Thompson Oak cores suggest a nearshore-marine environment. Sedimentary characteristics of the overlying Congaree beds suggest an open-marine shelf environment for deposits in the downdip core and a fluvially dominated to marginal-marine environment for deposits in the updip cores in the vicinity of Millers Pond. The Warley Hill Formation at Millhaven also was deposited in an open-marine shelf environment.

\section{SANTEE LIMESTONE}

The Santee Limestone consists predominantly of limestone and unlithified carbonate with a few beds of calcareous sand and clay. The Santee Limestone, as correlated in this report, includes lithologies assigned by others to the Warley Hill Formation (Steele, 1985; McClelland, 1987; Fallaw and Price, 1992, 1995), the Blue Bluff Marl of the Lisbon Formation (Huddlestun and Hetrick, 1986), the Santee Limestone (Sloan, 1908), and the McBean Formation (Veatch and Stephenson, 1911). These lithofacies are time equivalents of the Lisbon Formation of western Georgia (Prowell, Christopher, and others, 1985) and collectively are correlated as one package of sediment in this report (fig. 6), although we do recognize significant stratigraphic contacts within the unit. 
The lower part of the Santee Limestone in the Millhaven core from a depth of 401 to $365 \mathrm{ft}$ consists of calcareous sand with glauconite and pelecypods that grades into overlying sandy carbonate with large oyster shells and other pelecypods (fig. 3). The quartz sand is medium to coarse near the base of the section and fines upward to fine to medium. The carbonate in this part of the section ranges from unlithified to partially lithified. The contact between the lower and middle part of the section at $365 \mathrm{ft}$ is phosphatized and pyritized. Pelecypod-moldic pores immediately beneath the contact are filled with the very fine sediments of the overlying marl.

The middle part of the Santee Limestone in the Millhaven core from 365 to $245 \mathrm{ft}$ varies from marl to carbonate with very little quartz sand in both lithologies. Carbonate from 365 to $268 \mathrm{ft}$ is well lithified and has biomoldic porosity. The marl is burrow mottled to wavy laminated with minor amounts of lignite and pyrite. Fossils in the marl include foraminifers, spicules, shark teeth, pelecypods, and gastropods. The marl grades into overlying well-lithified to partially lithified limestone. Fossils in the limestone are more abundant and more diverse than in the marl and include pelecypods, gastropods, bryozoans, echinoids, foraminifers, brachiopods, and shark teeth. A sharp bedding contact at $332 \mathrm{ft}$ is underlain by biomoldic limestone with phosphatized fossil molds and shark teeth from 336 to 332 $\mathrm{ft}$. Porosity in the middle part of the section is interparticle and biomoldic with irregular dissolution cavities from 258 to $252 \mathrm{ft}$.

The sandy carbonate in the upper part of the Santee Limestone in the Millhaven core from 245 to $228 \mathrm{ft}$ includes fine to medium quartz sand and glauconite. Marine fossils include pelecypods, bryozoans, and gastropods.

The Santee Limestone in the Girard core includes a very sandy limestone from 325 to $322 \mathrm{ft}$ and a marl and clayey sand from 322 to $250 \mathrm{ft}$ (fig. 4). The limestone from 325 to $322 \mathrm{ft}$ is glauconitic with abundant pelecypod-moldic porosity and is pyritic along the contact with the overlying marl. The marl is a very fine grained limestone unit with as much as 30 percent clay matrix. Very fine to fine quartz sand ranges from 2 percent near the base of the section to 25 percent near the top of the section. The marl and calcareous sand are burrow mottled and contain minor amounts of lignite and glauconite. Macrofossils are sparse and include pelecypods.

The Santee Limestone in the Millers Pond core consists of sandy limestone and calcareous sand (fig. 5). A thin basal lag of very poorly sorted sand from 156 to $154 \mathrm{ft}$ includes quartz pebbles and granules, glauconite, and pelecypods. The quartz sand above $154 \mathrm{ft}$ is fine to very coarse in calcareous sand beds and fine to medium in sandy limestone beds. The limestone below a depth of $121 \mathrm{ft}$ is finely crystalline and contains glauconite and marine fossils, including pelecypods, spicules, foraminifers, and shark teeth. Marine fossils in the limestone above a depth of $100 \mathrm{ft}$ include oysters and other pelecypods, foraminifers, and echinoid fragments. Biomoldic porosity also is present above a depth of $100 \mathrm{ft}$ and reflects dissolution of aragonitic pelecypods and gastropods.

The Santee Limestone at Millers Pond is thicker than comparable sections in this updip area (Nystrom and Willoughby, 1982; Nystrom and others, 1986; McClelland, 1987; Prowell, 1994). McClelland (1987) described this unit as $40 \mathrm{ft}$ thick in a drill hole located west of the Millers Pond site. This information, in conjunction with the evidence for the section missing from the underlying Fourmile Branch/Congaree/Warley Hill Formation, suggests that the basal contact of the Santee Limestone represents scour into the underlying unit and is possibly the result of localized channeling. Observations of similar channeling have been reported in nearby strip mines (Nystrom and others, 1986).

The Santee Limestone section from 156 to $139 \mathrm{ft}$ in the Millers Pond core is biostratigraphically correlative with sections in the Millhaven core from 401 to $365 \mathrm{ft}$ and in the Girard core from 325 to $322 \mathrm{ft}$ and with samples collected at depths of 181.5, 174, 172, 164 and $154 \mathrm{ft}$ in the Thompson Oak core and $181 \mathrm{ft}$ in the McBean core (Edwards, this volume, chap. G; Bybell, this volume, chap. F; Frederiksen, this volume, chap. H). This part of the Santee Limestone in the studied cores is biostratigraphically equivalent to the upper part of the unit E4 (Prowell, Christopher, and others, 1985). Prowell, Christopher, and others (1985) identified their unit as correlative with part of the Warley Hill Formation underlying the southeastern part of the SRS. Gellici and others (1995) described a similar lithologic unit in the same stratigraphic position in the subsurface of Allendale County and designated the unit as the Warley Hill Formation. Steele (1985) and McClelland (1987) described a calcareous lithofacies of the Warley Hill Formation. Fallaw and Price (1995) described a sporadic sand lithofacies of the Warley Hill Formation at the base of the Tinker Formation in the updip part of the SRS.

The remainder of the Santee Limestone in the Millhaven, Girard, and Millers Pond cores is biostratigraphically equivalent to unit E5 (Prowell, Christopher, and others, 1985) and the Tinker Formation (Fallaw and Price, 1995). This part of the Santee Limestone is lithologically similar to the Blue Bluff Marl of the Lisbon Formation (Huddlestun and Hetrick, 1986), the Santee Limestone (Sloan, 1908), and the McBean Formation (Veatch and Stephenson, 1911). The siliciclastic lithologies of the Tinker Formation in South Carolina (Fallaw and Price, 1995) are correlative with the predominantly carbonate lithologies of the Santee Limestone but are not recognized in the Georgia cores.

Calcareous nannofossils, planktonic foraminifers, dinoflagellates, and pollen from the core localities indicate a late middle Eocene (late Claibornian) age for the Santee sections (Edwards and others, this volume, chap. B). Marine fossils and carbonate suggest that this unit was deposited in an open-marine, shallow-shelf environment. The distribu- 
tion of siliciclastic sediments and the diversity of marine fossils in the carbonate facies suggest that the updip Millers Pond core is more proximal to a source of siliciclastic sediments than the downdip Millhaven core.

\section{BARNWELL UNIT}

The Barnwell unit derives its name from the Barnwell Group (Huddlestun and Hetrick, 1979, 1986). The Barnwell Group consists of the Clinchfield Formation, Dry Branch Formation, and Tobacco Road Sand that have been described and mapped on both sides of the Savannah River in the vicinity of the SRS (Huddlestun and Hetrick, 1978, 1979, 1986; Huddlestun, 1982; Prowell, 1994; Fallaw and Price, 1995). The informally named Barnwell unit in this report includes strata of the Barnwell Group and the post-Eocene strata in the study area.

The Barnwell unit in the Millhaven core includes calcareous clay from a depth of 228 to $223 \mathrm{ft}$, and moderately well to well-sorted calcareous quartz sand and partially lithified sandy limestone from 223 to $123 \mathrm{ft}$ (fig. 3). The fine to medium sand includes 1 percent glauconite. Thin beds of silica-replaced limestone are common from a depth of 200 to $170 \mathrm{ft}$. The section from 123 to $54 \mathrm{ft}$ consists of unlithified carbonate and partially lithified limestone with generally less than 10 percent quartz sand and 1 percent glauconite. Irregularly shaped phosphatized limestone clasts at the base of this part of the section produce a sharp spike on the gamma-ray $\log$ at $123 \mathrm{ft}$. The unit from $54 \mathrm{ft}$ to land surface consists of a coarsening-upward sequence of clayey sand and sandy clay. Fossils observed in the core include pelecypods, bryozoans, echinoids, and foraminifers from 223 to $54 \mathrm{ft}$. Biomoldic pores are present from 67 to $34 \mathrm{ft}$ and reflect dissolution of aragonitic pelecypods and gastropods.

The Barnwell unit in the Girard core consists of clay, sand, and carbonate lithologies in the lower part of the section from 250 to $104 \mathrm{ft}$ and sand and clay in the upper part of the section from $104 \mathrm{ft}$ to land surface (fig. 4). A basal calcareous clay from 250 to $244 \mathrm{ft}$ is overlain by partially silicified, phosphatized, and glauconitic limestone from a depth of 244 to $234 \mathrm{ft}$; calcareous quartz sand from 234 to $193 \mathrm{ft}$; sandy limestone from 193 to $183 \mathrm{ft}$; marl from 183 to $136 \mathrm{ft}$; and a sandy limestone that grades into an overlying quartz sand from 136 to $104 \mathrm{ft}$. Fossils include pelecypods and bryozoans. Biomoldic porosity ranges from 5 to 20 percent in the limestone and reflects dissolution of aragonitic pelecypods. Sand is fine to coarse near the base and very fine to fine in the rest of the section from 250 to $104 \mathrm{ft}$. Clay matrix ranges from 20 to 40 percent in the sand. Clay laminae are abundant below $172 \mathrm{ft}$. The Barnwell unit from 104 $\mathrm{ft}$ to land surface is noncalcareous and contains clayey sand and clay. The sand ranges from fine to coarse and contains several flattened, ovoid pebbles at $88 \mathrm{ft}$.
The Barnwell unit at Millers Pond consists of siliciclastic sediments from a depth of $82 \mathrm{ft}$ to land surface. The contact with the Santee Limestone was not recovered in coring. A thin, irregularly shaped bed of limestone at $75 \mathrm{ft}$ is lithologically similar to the underlying Santee Limestone and is presumed to be a large reworked clast. The Barnwell unit from 78 to $67 \mathrm{ft}$ includes thin beds of fine to medium and fine to very coarse sand, and thin beds of well-laminated clay. The sand has fine lignite, clay clasts, and 10 to 20 percent clay matrix. The section from $67 \mathrm{ft}$ to land surface is a coarsening-upward sequence of sand and ranges from fine to medium sand up to fine to very coarse sand. The amount of clay matrix ranges from 5 to 25 percent. Sedimentary structures include clay laminae and clay wisps from 66 to $62 \mathrm{ft}, 48$ to $47 \mathrm{ft}$, and 38 to $27 \mathrm{ft}$. The sand from 49 to $42 \mathrm{ft}$ contains granules and pebbles. The Barnwell unit is mapped as the uppermost stratigraphic unit at the Millers Pond site (Prowell, 1994), where it includes the Tobacco Road Sand and Irwinton Sand Member of the Dry Branch Formation. Partial recovery of sediments during coring makes selection of a formation contact within the Barnwell unit difficult.

The contact between the Barnwell Group and a post-Eocene unit, as mapped in the area of the Girard site (Prowell, 1994), was not identified in the Girard core. The post-Eocene unit was described and designated as map unit Tu (Prowell, 1994). The mapped contact was projected to a depth of $50 \mathrm{ft}$ in the Girard section. A lag deposit and other evidence of an unconformity, if present in the Girard section, were not recovered during coring at this depth. The presence of post-Eocene sediments is acknowledged at the Girard site on the basis of previous studies, but a separate unit is not defined at this time.

Paleontologic data for the Millhaven and Girard cores suggest a late Eocene to questionably early Oligocene age for the Barnwell sections (Edwards and others, this volume, chap. B). The Barnwell unit is equivalent to units E6, E7, E8, and Ml (Prowell, Christopher, and others, 1985) and the Clinchfield Formation, Dry Branch Formation, and Tobacco Road Sand of the Barnwell Group at the SRS (Fallaw and Price, 1995). Throughout the study area, the abundance of carbonate, the presence of glauconite and phosphate, and the abundance of marine macrofossils and microfossils in the calcareous part of the section indicate that the Barnwell strata were deposited in open-marine environments. The calcareous sand probably was deposited in a shallow-shelf environment, and the fossil bed at the base is a lag deposit produced by a late Eocene marine transgression. The noncalcareous sand and clay, the ovoid flattened pebbles, and the clay wisps in the upper part of the Barnwell unit suggest that these strata were deposited in nearshore-marine environments. 


\section{SUMMARY}

Five deep stratigraphic test holes were drilled from 1991 to 1993 in support of multidisciplinary investigations to determine the stratigraphy of Upper Cretaceous and Tertiary sediments of the coastal plain in east-central Georgia. Cored sediment and geophysical logs from the Millhaven test hole in Screven County and the Girard and Millers Pond test holes in Burke County are the primary sources of lithologic and paleontologic information for this report. Lithologic and paleontologic information from the Thompson Oak and McBean test holes in Burke County supplement the discussion of stratigraphy and sedimentation in the updip part of the study area near the Millers Pond test hole.

The Cretaceous sections in the studied cores are divided into the Cape Fear Formation, the Middendorf Formation, the Black Creek Group, and the Steel Creek Formation. These four geologic units consist of siliciclastic sediments. Evidence of possible unconformities is used to recognize two subunits in the Middendorf Formation and three subunits in the Black Creek Group. Sediments in the Cretaceous section generally are coarser grained and more oxidized in updip areas. Each contact between units is considered to be a regional unconformity and denotes a considerable hiatus in sedimentation. The sediments in all four units have been interpreted as being part of large deltaic systems that prograded across the paleo-continental shelf in east-central Georgia and western South Carolina. The lithofacies observed in the Upper Cretaceous units tend to be coarser grained in proximal-deltaic environments and finer grained in distal-deltaic environments.

The Tertiary sections are divided into the Ellenton and Snapp Formations of Paleocene age; the Fourmile Branch/Congaree/Warley Hill unit and Santee Limestone of Eocene age; and the Barnwell unit, which contains strata of Eocene to Miocene age. The Tertiary section, with the exception of the Snapp Formation, generally is more calcareous and has a more diverse and abundant marine microflora and fauna in the downdip Millhaven core, relative to the updip McBean and Millers Pond cores. For these units, sedimentary and paleontologic evidence suggests openmarine shelf environments at the Millhaven site and marginal-marine environments at the Millers Pond site.

The Ellenton Formation in the Georgia cores is finer grained, calcareous, and very glauconitic in the downdip Millhaven and Girard cores. It is coarser grained and noncalcareous in the updip Millers Pond core. Lag deposits and sharp bedding contacts identify basal unconformities and possible unconformities within the Georgia sections.

The Snapp Formation is nearly barren of fossils and is a noncalcareous sequence of oxidized sand and clay. Sedimentary characteristics of the Snapp Formation suggest a fluvially dominated depositional environment such as an upper delta plain or an incised alluvial valley. The presence of a sparse marine microflora suggests some marine influ- ence on deposition in the downdip area near Millhaven. Differences in the thickness of this formation in the study area suggest that channels containing the basal sand of the Snapp Formation are incised into laminated black clay of the Ellenton Formation.

The lithologies of the Fourmile Branch/Congaree/Warley Hill unit range from mixed-siliciclastic-carbonate sections in the central and downdip Georgia cores to siliciclastic sections in the updip cores. Paleontologic data suggest that the strata in this unit are correlative with three formally named formations at the SRS. However, all three formations are not consistently present in each of the Georgia cores.

The Santee Limestone consists predominantly of limestone and unlithified carbonate with a few beds of calcareous sand and clay. The Santee Limestone, as correlated in this report, includes lithologies assigned by others to the Warley Hill Formation, the Blue Bluff Marl of the Lisbon Formation, the Santee Limestone, and the McBean Formation. These lithofacies are time equivalents of the Lisbon Formation of western Georgia and collectively are correlated as one package of sediment in this report.

The informally named Barnwell unit in this report includes strata of the Barnwell Group and the post-Eocene strata in the study area. The presence of post-Eocene sediments is acknowledged at the Girard site on the basis of previous studies, but a separate unit is not defined at this time.

\section{REFERENCES CITED}

Bechtel Corporation, 1972, Applicants environmental report, volumes I and II-Alvin W. Vogtle Nuclear Plant: unpublished report for Georgia Power Company, Atlanta, Georgia; report on file at U.S. Geological Survey, Doraville, GA 30360.

-1973, Preliminary safety analysis report, volumes II and III-Alvin W. Vogtle Nuclear Plant: unpublished report for Georgia Power Company, Atlanta, Georgia; report on file at U.S. Geological Survey, Doraville, GA 30360.

1982, Studies of postulated Millett fault, Georgia Power Company Vogtle Nuclear Plant: San Francisco, Bechtel Corporation, unpublished report, volumes 1 and 2, variously paged.

Bledsoe, H.W., 1984, SRP baseline hydrogeologic investigationPhase I: E.I. du Pont de Nemours and Company, Savannah River Laboratory, Aiken, S.C., DPST-84-833, 102 p.

1987, SRP baseline hydrogeologic investigation-Phase II: E.I. du Pont de Nemours and Company, Savannah River Laboratory, Aiken, S.C., DPST-86-674, 296 p.

1988, SRP baseline hydrogeologic investigation-Phase III: E.I. du Pont de Nemours and Company, Savannah River Laboratory, Aiken, S.C., DPST-88-627, 294 p.

Brantley, J.E., 1916, A report on the limestones and marls of the coastal plain of Georgia: Georgia Geological Survey Bulletin $21,300 \mathrm{p}$. 
Buie, B.F., 1978, The Huber Formation of eastern-central Georgia, in Short contributions to the geology of Georgia: Georgia Geologic Survey Bulletin 93, p. 1-7.

Carver, R.E., 1972, Stratigraphy of the Jackson Group in eastern Georgia: Southeastern Geology, v. 14, p. 153-181.

Christl, R.J., 1964, Storage of radioactive wastes in basement rock beneath the Savannah River Plant: E. I. du Pont de Nemours and Company, Report DP-844, 105 p.

Christopher, R.A., 1978, Quantitative palynologic correlation of three Campanian and Maastrichtian sections (Upper Cretaceous) from the Atlantic Coastal Plain: Palynology, v. 2, p. 127.

1982, Palynostratigraphy of the basal Cretaceous units of the eastern Gulf and southern Atlantic Coastal Plains, in Arden, D.D., Beck, B.F., and Morrow, Eleanore, eds., Proceedings; Second symposium on the geology of the southeastern coastal plain: Georgia Geologic Survey Information Circular 53, p. 10-23, pls. 1-3.

Christopher, R.A., Owens, J.P., and Sohl, N.F., 1979, Late Cretaceous palynomorphs from the Cape Fear Formation of North Carolina: Southeastern Geology, v. 20, no. 3, p. 145-159.

Clarke, J.S., Brooks, Rebekah, and Faye, R.E., 1985, Hydrogeology of the Dublin and Midville aquifer systems of east-central Georgia: Georgia Geologic Survey Information Circular 74, $62 \mathrm{p}$.

Clarke, J.S., Falls, W.F., Edwards, L.E., [Bukry, David,] Frederiksen, N.O., Bybell, L.M., Gibson, T.G., Gohn, G.S., and Fleming, Farley, 1996, Hydrogeologic data and aquifer interconnection in a multi-aquifer system in coastal plain sediments near Millhaven, Screven County, Georgia, 1991-95: Georgia Geologic Survey Information Circular 99, 43 p., 1 pl. in pocket.

Clarke, J.S., Falls, W.F., Edwards, L.E., Frederiksen, N.O., Bybell, L.M., Gibson, T.G., and Litwin, R.J., 1994 [1995], Geologic, hydrologic and water-quality data for a multi-aquifer system in coastal plain sediments near Millers Pond, Burke County, Georgia, 1992-93: Georgia Geologic Survey Information Circular 96, 34 p., 1 pl. in pocket.

Colquhoun, D.J., coordinator, 1991, Southeastern Atlantic regional cross section, eastern and offshore, South Carolina and Georgia sector: Tulsa, Okla., American Association of Petroleum Geologists.

1992, Observations on general allostratigraphy and tectonic framework of the southeastern Atlantic coast regional cross section (DNAG E-5 corridor) Georgia and South Carolina as they relate to the Savannah River Site, in Fallaw, W.C., and Price, Van, eds., Geological investigations of the central Savannah River area, South Carolina and Georgia (Carolina Geological Society field trip guidebook, November 13-15, 1992): U.S. Department of Energy and South Carolina Geological Survey, p. CGS-92-B.I.1-B.I.8.

Colquhoun, D.J., and Muthig, M.G., 1991, Stratigraphy and structure of the Paleocene and lower Eocene Black Mingo Group, in Horton, J.W., Jr., and Zullo, V.A., eds., Geology of the Carolinas: Knoxville, Tenn., University of Tennessee Press, p. 241-250.

Colquhoun, D.J., and Steele, K.B., 1985, Chronostratigraphy and hydrostratigraphy of the northwestern South Carolina Coastal Plain: Project No. G868-05, Annual Cooperative Grant Agreement No. 13040 R-83-591, Interim Technical Report to Water Resources Research Institute, Clemson University, Clemson, S.C., 15 p.

Colquhoun, D.J., Woollen, I.D., Van Nieuwenhuise, D.S., Padgett, G.G., Oldham, R.W., Boylan, D.C., Bishop, J.W., and Howell, P.D., 1983, Surface and subsurface stratigraphy, structure and aquifers of the South Carolina Coastal Plain: Columbia, S.C., University of South Carolina, Department of Geology, Report to the Department of Health and Environmental Control, Ground-water Protection Division, published through the Office of the Governor, State of South Carolina, $79 \mathrm{p}$.

Cooke, C.W., 1936, Geology of the coastal plain of South Carolina: U.S. Geological Survey Bulletin 867, 196 p.

1943, Geology of the coastal plain of Georgia: U.S. Geological Survey Bulletin 941, $121 \mathrm{p}$.

Cooke, C.W., and MacNeil, F.S., 1952, Tertiary stratigraphy of South Carolina: U.S. Geological Survey Professional Paper 243-B, p. 19-29.

Cooke, C.W., and Shearer, H.K., 1918, Deposits of Claiborne and Jackson age in Georgia: U.S. Geological Survey Professional Paper 120-C, p. 41-81.

Daniels, D.L., 1974, Geologic interpretation of geophysical maps, central Savannah River area, South Carolina and Georgia: U.S. Geological Survey Geophysical Investigations Map GP893, 10-p. text, 3 sheets, scales 1:250,000 and 1:500,000.

Dennehy, K.F., Prowell, D.C., and McMahon, P.B., 1989, Reconnaisance hydrogeologic investigation of the Defense Waste Processing Facility and vicinity, Savannah River Plant, South Carolina: U.S. Geological Survey Water-Resources Investigations Report, WRI 88-4221, 74 p.

Edwards, L.E., 1992, Dinocysts from the lower Tertiary units in the Savannah River area, South Carolina and Georgia, in Zullo, V.A., Harris, W.B., and Price, Van, eds., Savannah River region; transition between the Gulf and Atlantic Coastal Plains: Proceedings of the Second Bald Head Island Conference on Coastal Plains Geology, Hilton Head Island, November 6-11, 1990, p. 97-99.

Fallaw, W.C., and Price, Van, eds., 1992, Geological investigations of the central Savannah River area, South Carolina and Georgia (Carolina Geological Society field trip guidebook, November 13-15, 1992): U.S. Department of Energy and South Carolina Geological Survey, variously paged [112 p.].

1995, Stratigraphy of the Savannah River Site and vicinity: Southeastern Geology, v. 35, no. 1, p. 21-58.

Fallaw, W.C., Price, Van, and Thayer, P.A., 1992a, Cretaceous lithofacies of the Savannah River Site, South Carolina, in Zullo, V.A., Harris, W.B., and Price, Van, eds., Savannah River region; transition between the Gulf and Atlantic Coastal Plains: Proceedings of the Second Bald Head Island Conference on Coastal Plains Geology, Hilton Head Island, November 6-11, 1990, p. 50-51.

1992b, Stratigraphy of the Savannah River Site, South Carolina, in Zullo, V.A., Harris, W.B., and Price, Van, eds., Savannah River region; transition between the Gulf and Atlantic Coastal Plains: Proceedings of the Second Bald Head Island Conference on Coastal Plains Geology, Hilton Head Island, November 6-11, 1990, p. 29-32.

Falls, W.F., Baum, J.S., and Prowell, D.C., 1997, Physical stratigraphy and hydrostratigraphy of Upper Cretaceous and Paleocene sediments, Burke and Screven Counties, Georgia: Southeastern Geology, v. 36, no. 4, p. 153-176. 
Faye, R.E., and Prowell, D.C., 1982, Effects of Late Cretaceous and Cenozoic faulting on the geology and hydrology of the Coastal Plain near the Savannah River, Georgia and South Carolina: U.S. Geological Survey Open-File Report 82-156, 75 p., 8 sheets.

Gellici, J.A., Reed, R.H., Logan, W.R., Aadland, R.K., and Simones, G.C., 1995, Hydrogeologic investigation and establishment of a permanent multi-observation well network in Aiken, Allendale, and Barnwell Counties, South CarolinaEight-year interim report (1986-1994): South Carolina Department of Natural Resources, Water Resources Division, Open-File Report 1, volumes 1 and 2, 417 p., 9 pls.

Gohn, G.S., 1992, Revised nomenclature, definitions, and correlations for the Cretaceous Formations in USGS-Clubhouse Crossroads \#1, Dorchester County, South Carolina: U.S. Geological Survey Professional Paper 1518, 39 p., 1 pl. in pocket.

Harris, W.B., and Zullo, V.A., 1992, Sequence stratigraphy of Paleocene and Eocene deposits in the Savannah River region, in Zullo, V.A., Harris, W.B., and Price, Van, eds., Savannah River region; transition between the Gulf and Atlantic Coastal Plains: Proceedings of the Second Bald Head Island Conference on Coastal Plains Geology, Hilton Head Island, November 6-11, 1990, p. 134-142.

Herrick, S.M., 1960, Some small Foraminifera from Shell Bluff, Georgia: Bulletins of American Paleontology, v. 41, p. 117127.

-1961, Well logs of the coastal plain of Georgia: Georgia Geologic Survey Bulletin 70, 462 p.

1964, Upper Eocene small Foraminifera from Shell Bluff and Griffins Landing, Burke County, Georgia: U.S. Geological Survey Professional Paper 501-C, p. C64-C65.

1972, Age and correlation of the Clinchfield Sand of Georgia: U.S. Geological Survey Bulletin 1354-E, 17 p.

Herrick, S.M., and Counts, H.B., 1968, Late Tertiary stratigraphy of eastern Georgia: Georgia Geological Society, 3d Field Trip Guidebook, 88 p.

Herrick, S.M., and Vorhis, R.C., 1963, Subsurface geology of the Georgia Coastal Plain: Georgia Geologic Survey Information Circular 25, $78 \mathrm{p}$.

Hetrick, J.H., 1992, A geologic atlas of the Wrens-Augusta area: Georgia Geologic Survey Geologic Atlas 8, 3 pls.

Huddlestun, P.F., 1982, The development of the stratigraphic terminology of the Claibornian and Jacksonian marine deposits of western South Carolina and eastern Georgia, in Nystrom, P.G., Jr., and Willoughby, R.H., eds., Geological investigations related to the stratigraphy in the kaolin mining district, Aiken County, South Carolina (Carolina Geological Society Field Trip Guidebook for 1982): Columbia, S.C., South Carolina Geological Survey, p. 21-33.

1988, A revision of the lithostratigraphic units of the coastal plain of Georgia, Miocene through Holocene: Georgia Geologic Survey Bulletin 104, 162 p.

1992, Upper Claibornian coastal marine sands of eastern Georgia and the Savannah River area, in Fallaw, W.C., and Price, Van, eds., Geological investigations of the central Savannah River area, South Carolina and Georgia (Carolina Geological Society field trip guidebook, November 13-15, 1992): U.S. Department of Energy and South Carolina Geological Survey, p. CGS-92-B.XII.1-B.XII.6.
Huddlestun, P.F., and Hetrick, J.H., 1978, Stratigraphy of the Tobacco Road Sand-A new formation: Georgia Geologic Survey Bulletin 93, p. 56-77.

1979, The stratigraphy of the Barnwell Group of Georgia: Georgia Geologic Survey Open File Report 80-1, 89 p. [Published for the 14th Field Trip of the Georgia Geological Society.]

1986, Upper Eocene stratigraphy of central and eastern Georgia: Georgia Geologic Survey Bulletin 95, 78 p.

1991, The stratigraphic framework of the Fort Valley Plateau and the central Georgia kaolin district-Guidebook for the 26th annual field trip: Georgia Geological Society Guidebook, v. 11, no. 1, 119 p.

Huddlestun, P.F., and Summerour, J.H., 1996, The lithostratigraphic framework of the uppermost Cretaceous and lower Tertiary of eastern Burke County, Georgia: Georgia Geologic Survey Bulletin 127, 94 p.

Hurst, V.J., Crawford, T.J., and Sandy, John, 1966, Mineral resources of the central Savannah River area: Washington, D.C., U.S. Economic Development Administration, 2 v. (v. 1, 467 p., v. 2, 231 p.).

Kidd, N.B., 1996, Determination of the hydraulic properties of coastal plain aquifers at Millers Pond and Millhaven, east-central Georgia: Clemson, S.C., Clemson University, M.S. thesis, $153 \mathrm{p}$.

LaMoreaux, P.E., 1946a, Geology and ground-water resources of the coastal plain of east-central Georgia: Georgia Geologic Survey Bulletin 52, $173 \mathrm{p}$.

$1946 \mathrm{~b}$, Geology of the coastal plain of east-central Georgia: Georgia Geologic Survey Bulletin 50, 26 p.

Leeth, D.C., Falls, W.F., Edwards, L.E., Frederiksen, N.O., and Fleming, R.F., 1996, Geologic, hydrologic, and water-chemistry data for a multi-aquifer system in coastal plain sediments near Girard, Burke County, Georgia, 1992-95: Georgia Geologic Survey Information Circular 100, 26 p., 1 pl. in pocket.

Leeth, D.C., and Nagle, D.D., 1996, Shallow subsurface geology of part of the Savannah River alluvial valley in the upper coastal plain of Georgia and South Carolina: Southeastern Geology, v. 36, no. 1, p. 1-14.

LeGrand, H.E., and Furcon, A.S., 1956, Geology and ground-water resources of central-east Georgia: Georgia Geologic Survey Bulletin 64, $164 \mathrm{p}$.

Logan, W.R., and Euler, G.M., 1989, Geology and ground-water resources of Allendale, Bamberg, and Barnwell Counties and part of Aiken County, South Carolina: South Carolina Water Resources Commission Report 155, 113 p.

Marine, I.W., 1979, Hydrology of buried crystalline rocks at the Savannah River Plant near Aiken, South Carolina: U.S. Geological Survey Open-File Report 79-1544, 160 p.

Marine, I.W., and Siple, G.E., 1974, Buried Triassic basin in the central Savannah River area, South Carolina and Georgia: Geological Society of America Bulletin, v. 85, p. 311-320.

McClelland, S.A., 1987, Surface and subsurface stratigraphy of Cretaceous and younger strata along the Savannah River from southern Richmond County through Burke County, Georgia: Columbia, S.C., University of South Carolina, M.S. thesis, $123 \mathrm{p}$.

Nystrom, P.G., Jr., and Willoughby, R.H., eds., 1982, Geological investigations related to the stratigraphy in the kaolin mining district, Aiken County, South Carolina (Carolina Geological 
Society Field Trip Guidebook for 1982): Columbia, S.C., South Carolina Geological Survey, 183 p.

Nystrom, P.G., Jr., Willoughby, R.H., and Kite, L.E., 1986, Cretaceous-Tertiary stratigraphy of the upper edge of the coastal plain between North Augusta and Lexington, South Carolina (Carolina Geological Society Field Trip Guidebook for 1986): Columbia, S.C., South Carolina Geological Survey, 82 p.

Nystrom, P.G., Jr., Willoughby, R.H., and Price, L.K., 1991, Cretaceous and Tertiary stratigraphy of the upper coastal plain, South Carolina, in Horton, J.W., Jr., and Zullo, V.A., eds., Geology of the Carolinas: Knoxville, Tenn., University of Tennessee Press, p. 221-240.

Owens, J.P., 1989, Geologic map of the Cape Fear region, Florence $1^{\circ} \times 2^{\circ}$ quadrangle and northern half of the Georgetown $1^{\circ} \times 2^{\circ}$ quadrangle, North Carolina and South Carolina: U.S. Geological Survey Miscellaneous Investigations Series Map I-1948A, 2 sheets, scale 1:250,000.

Price, Van, Fallaw, W.C., and McKinney, J.B., 1991, Geologic setting of the new production reactor reference site with the Savannah River Site (U): Westinghouse Savannah River Company-Savannah River Site, Report WSRC-RP-91-96, 80 p.

Prowell, D.C., 1994, Preliminary geologic map of the Barnwell $30 ' \times 60 '$ quadrangle, South Carolina and Georgia: U.S. Geological Survey Open-File Report 94-673, 88 p.

Prowell, D.C., Christopher, R.A., Edwards, L.E., Bybell, L.M., and Gill, H.E., 1985 [1986], Geologic section of the updip coastal plain from central Georgia to western South Carolina: U.S. Geological Survey Miscellaneous Field Studies Map MF1737, 10-p. text, 1 sheet.

Prowell, D.C., Edwards, L.E., and Frederiksen, N.O., 1985 [1986], The Ellenton Formation in South Carolina-A revised age designation from Cretaceous to Paleocene, in Stratigraphic notes, 1984: U.S. Geological Survey Bulletin 1605-A, p. A63-A69.

Prowell, D.C., and O'Connors, B.J., 1978, Belair fault zone-Evidence of Tertiary fault displacement in eastern Georgia: Geology, v. 6 , no. 10 , p. 681-684.

Robertson, C.G., 1990, A textural, petrographic, and hydrogeological study of the Congaree Formation at the Savannah River Site, South Carolina: Wilmington, N.C., University of North Carolina, M.S. thesis, 65 p.

Schroder, C.H., 1982, Trace fossils of the Oconee Group and basal Barnwell Group of east-central Georgia: Georgia Geologic Survey Bulletin 88, 125 p.

Scrudato, R.J., and Bond, T.A., 1972, Cretaceous-Tertiary boundary of east-central Georgia and west-central South Carolina: Southeastern Geology, v. 14, p. 233-239.
Siple, G.E., 1967, Geology and ground water of the Savannah River Plant and vicinity, South Carolina: U.S. Geological Survey Water-Supply Paper 1841, 113 p.

Sloan, Earle, 1908, Catalogue of mineral localities of South Carolina: South Carolina Geological Survey, ser. 4, Bulletin 2, p. 449-453.

Smith, G.E., III, 1979, Stratigraphy of the Aiken County Coastal Plain: South Carolina Geological Survey Open-File Report 19, $34 \mathrm{p}$.

Snipes, D.S., 1965, Stratigraphy and sedimentation of the Middendorf Formation between Lynches River, South Carolina, and the Ocmulgee River, Georgia: Chapel Hill, N.C., University of North Carolina, Ph.D. dissertation, 140 p.

Snipes, D.S., Fallaw, W.C., Price, Van, and Cumbest, R.J., 1993, The Pen Branch fault; documentation of Late Cretaceous-Tertiary faulting in the coastal plain of South Carolina: Southeastern Geology, v. 33, no. 4, p. 195-218.

Sohl, N.F., and Owens, J.P., 1991, Cretaceous stratigraphy of the Carolina Coastal Plain, in Horton, J.W., Jr., and Zullo, V.A., eds., Geology of the Carolinas: Knoxville, Tenn., University of Tennessee Press, p. 191-220.

Steele, K.B., 1985, Lithostratigraphic correlation of Cretaceous and younger strata of the Atlantic Coastal Plain Province within Aiken, Allendale and Barnwell Counties, South Carolina: Columbia, S.C., University of South Carolina, M.S. thesis, $174 \mathrm{p}$.

Summerour, J.H., Shapiro, E.A., Lineback, J.A., Huddlestun, P.F., and Hughes, A.C., 1994, An investigation of tritium in the Gordon and other aquifers in Burke County, Georgia: Georgia Geologic Survey Information Circular 95, 93 p.

Van Nieuwenhuise, D.S., and Colquhoun D.J., 1982, The Paleocene-lower Eocene Black Mingo Group of the east-central coastal plain of South Carolina: South Carolina Geology, v. 26, no. 2, p. 47-67.

Veatch, Otto, and Stephenson, L.W., 1911, Preliminary report on the coastal plain of Georgia: Georgia Geologic Survey Bulletin $26,446 \mathrm{p}$.

Zullo, V.A., Willoughby, R.H., and Nystrom, P.G., Jr., 1982, A late Oligocene or early Miocene age for the Dry Branch Formation and Tobacco Road Sand in Aiken County, South Carolina, in Nystrom, P.G., Jr., and Willoughby, R.H., eds., Geological investigations related to the stratigraphy in the kaolin mining district, Aiken County, South Carolina (Carolina Geological Society Field Trip Guidebook for 1982): Columbia, S.C., South Carolina Geological Survey, p. 34-46. 